U.S. Department of the Interior Bureau of Land Management

Lakeview District Office

1000 South 9th Street, P.O. Box 151

Lakeview, Oregon 97630

\title{
High Desert Management Framework Plan Amendment and Record of Decision for the Lake Abert Area of Critical Environmental Concern (ACEC) in Lake County, Oregon
}

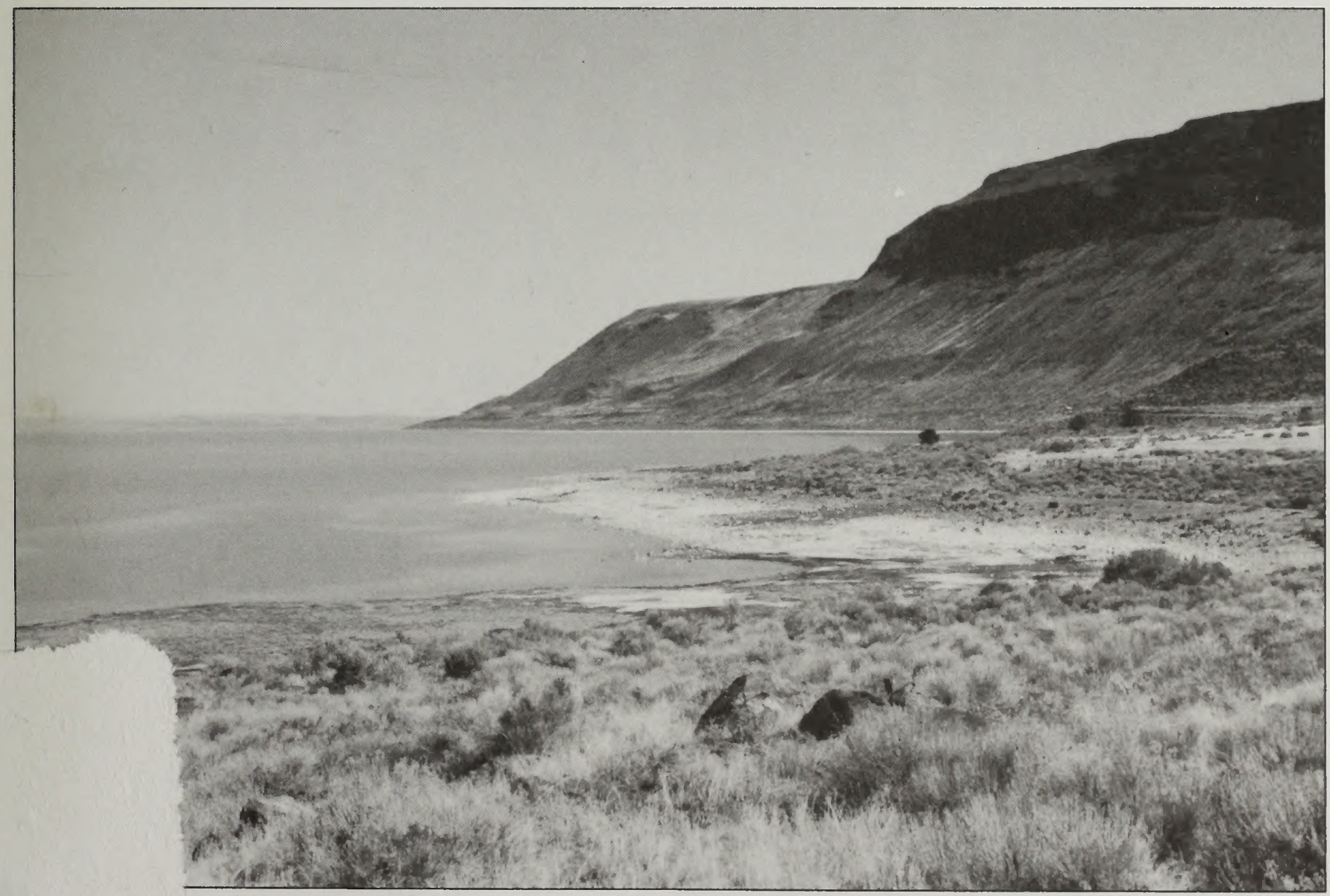


As the Nation's principal conservation agency, the Department of the Interior has responsibility for most of our nationally owned public lands and natural resources. This includes fostering the wisest use of our land and water resources, protecting our fish and wildlife, preserving the environmental and cultural values of our national parks and historical places, and providing for the enjoyment of life through outdoor recreation. The Department assesses our energy and mineral resources and works to assure that their development is in the best interest of all our people. The Department also has a major responsibility for American Indian reservation communities and for people who live in Island Territories under U.S. administration.

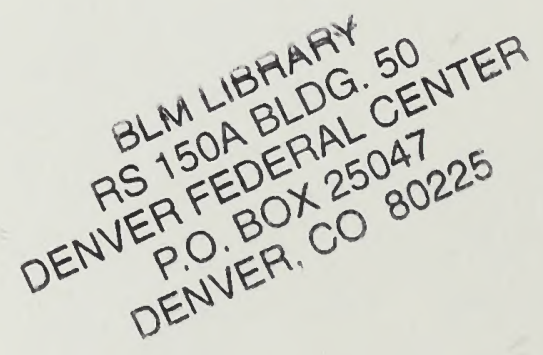




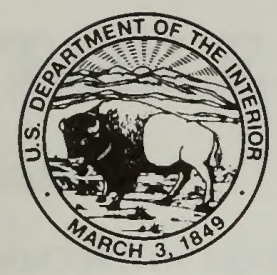

\title{
United States Department of the Interior
}

\author{
BUREAU OF LAND MANAGEMENT \\ Lakeview District Office \\ P.O. Box 151 (1000 Ninth Street S.) \\ Lakeview, Oregon 97630
}

IN REPLY REFER TO:

August 12, 1996

Dear Public Land User:

Enclosed is the Approved High Desert Management Framework Plan Amendment and Record of Decision for the Lake Abert Area of Critical Environmental Concern (ACEC). The Bureau of Land Management (BLM) has prepared this document in accordance with the Federal Land Policy and Management Act of 1976 and the National Environmental Policy Act of 1969.

A total of two comment letters and one protest letter were received during the review of the Proposed Plan Amendment/Final Environmental Impact Statement. These comments were addressed individually in writing and the protest has been resolved by the BLM Director. The protest resulted in minor clarifications of existing policy or plan implementation intent, but did not involve substantive changes requiring additional public notice or review.

This document contains the BLM State Director's decision to designate the area as an ACEC within the Record of Decision and a description of the special management required to protect the four resource values (cultural, wildlife, scenic, and ecological processes) for which the ACEC was designated. This decision has been announced within the Federal Register and local newspapers.

Thank you for your continued interest in the management of your public lands and the Lake Abert area in particular.

Sincerely,

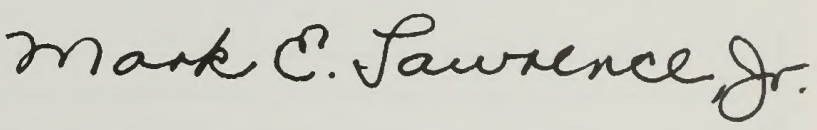

Mark Lawrence

Acting District Manager

Lakeview District

Enclosure, as stated

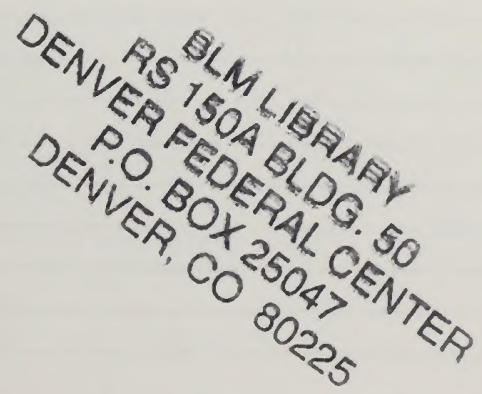




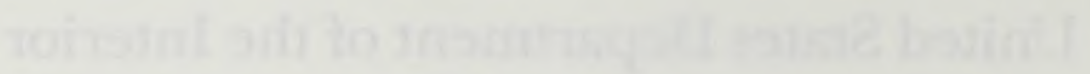

2 


\section{TABLE OF CONTENTS}

Subject

RECORD OF DECISION FOR THE HIGH DESERT MANAGEMENT

FRAMEWORK PLAN AMENDMENT FOR THE LAKE ABERT AREA

OF CRITICAL ENVIRONMENTAL CONCERN (ACEC) IN LAKE

COUNTY, OREGON

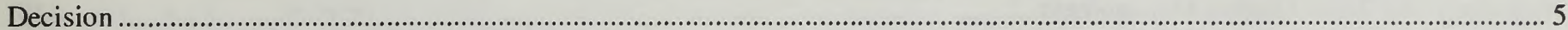

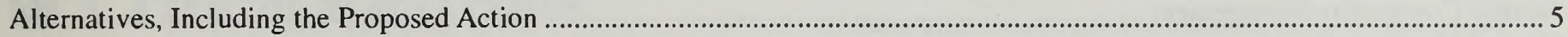

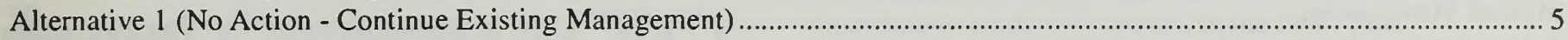

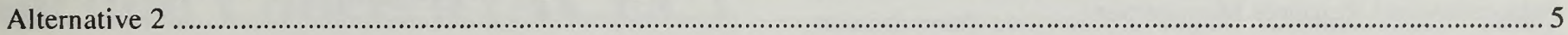

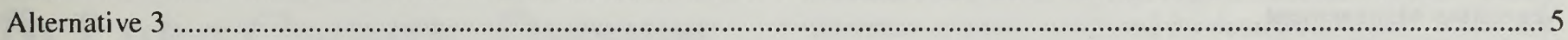

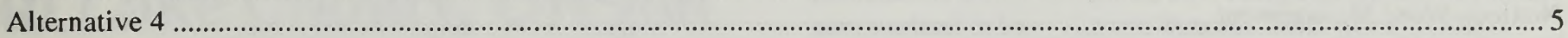

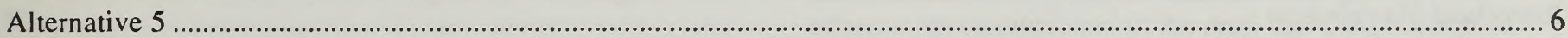

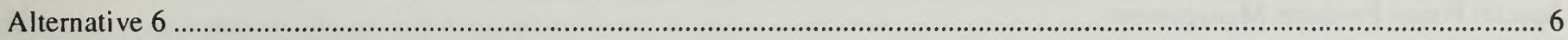

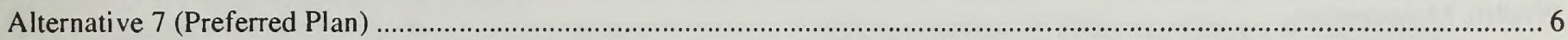

Environmental Preferability of the Alternatives …

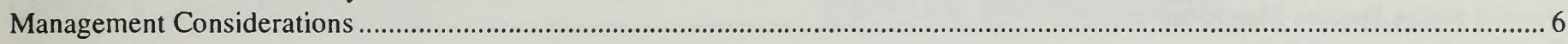

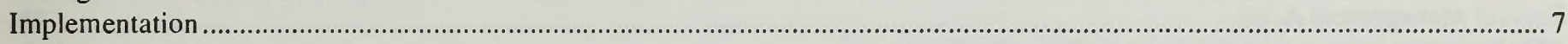

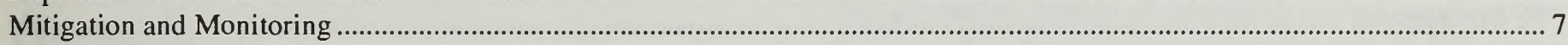

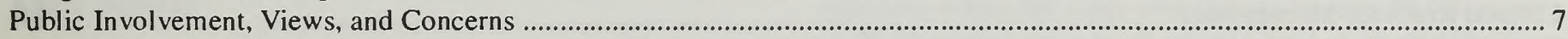

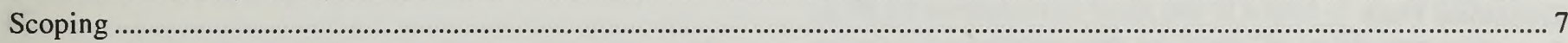

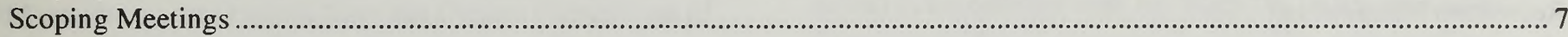

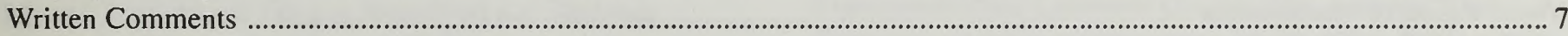

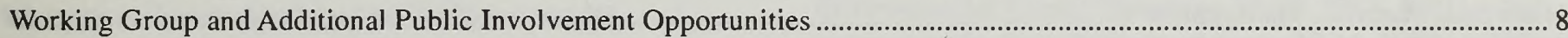

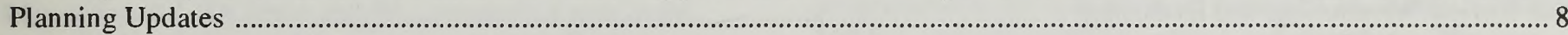

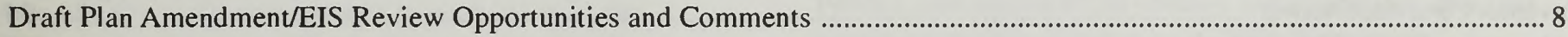

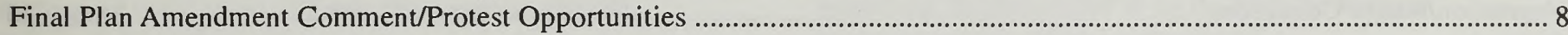

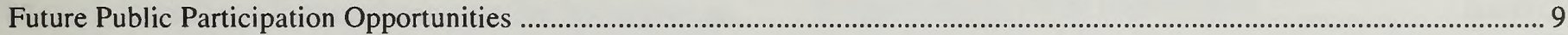

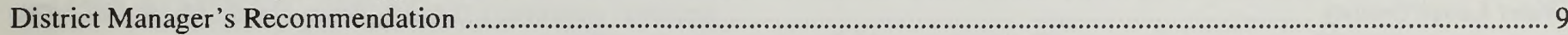

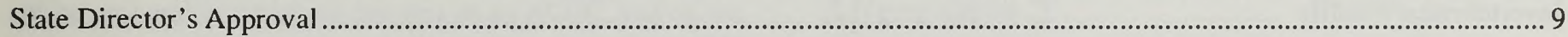

HIGH DESERT MANAGEMENT FRAMEWORK APPROVED PLAN

AMENDMENT FOR THE LAKE ABERT AREA OF CRITICAL

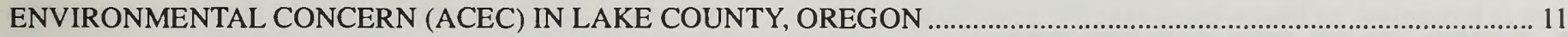

Planning Area

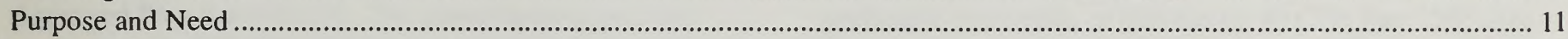

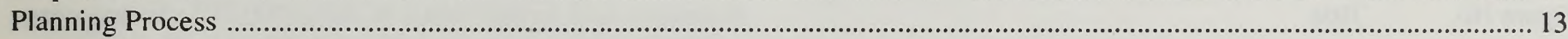

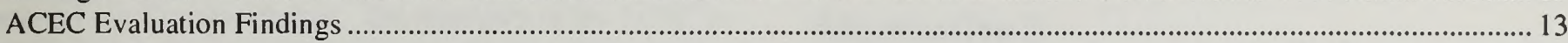

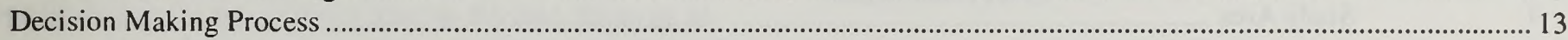

Relationship to Federal, State, Local, and Tribal Land Use Plans and Policies .............................................................. 13

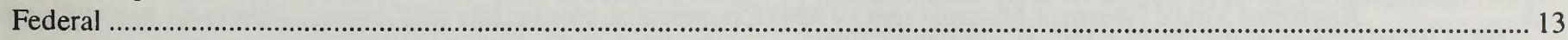

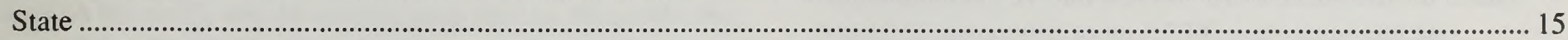

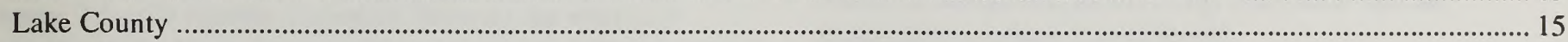

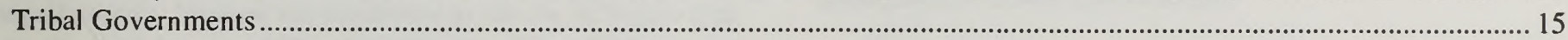

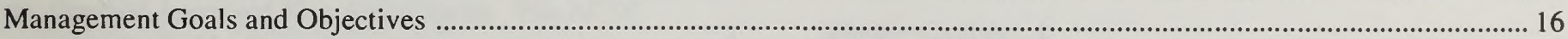

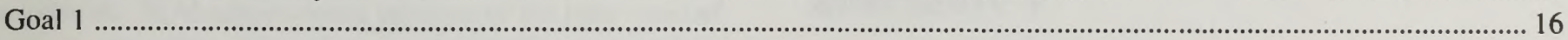

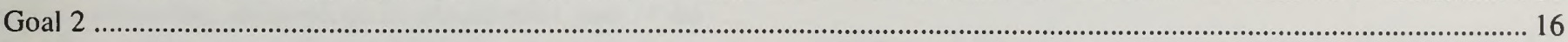

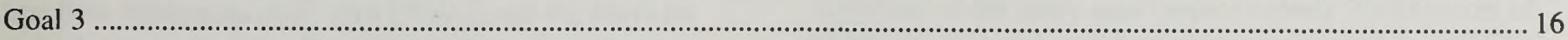

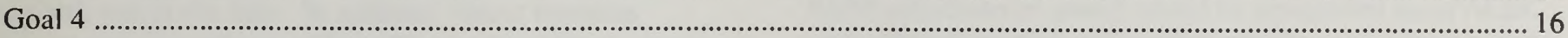

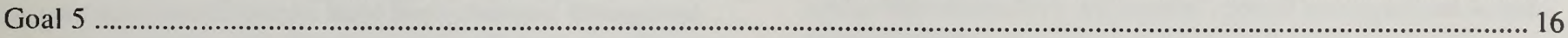

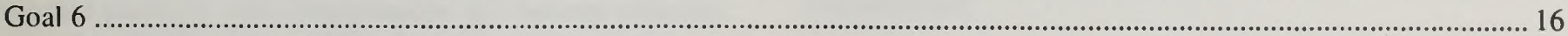

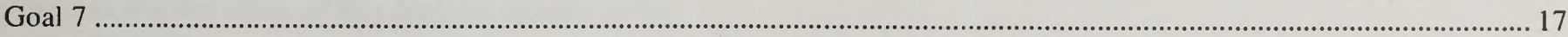


Goal 8

Goal 9

Goal 10

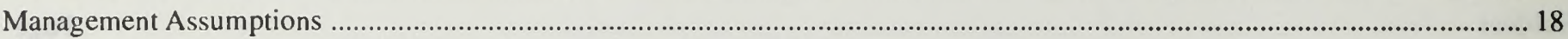

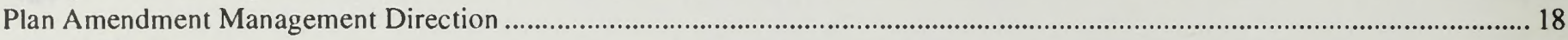

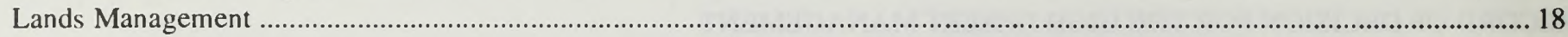

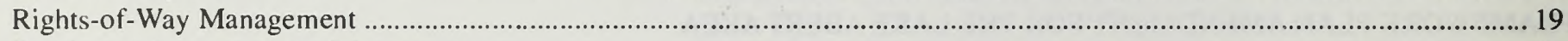

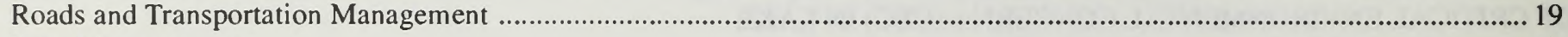

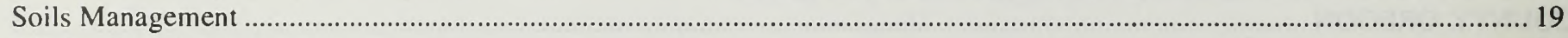

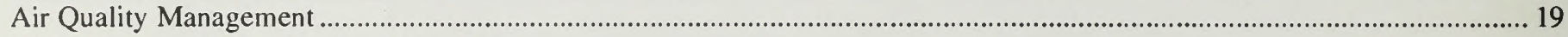

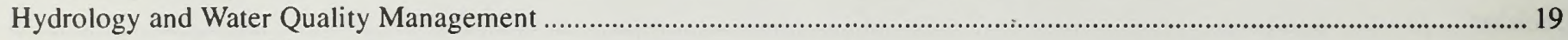

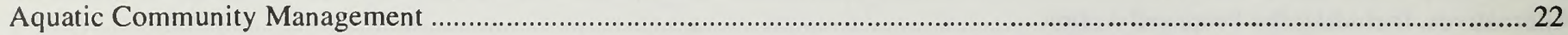

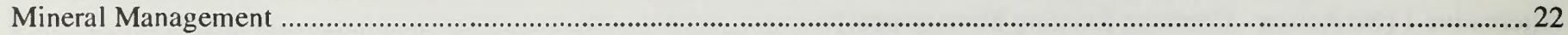

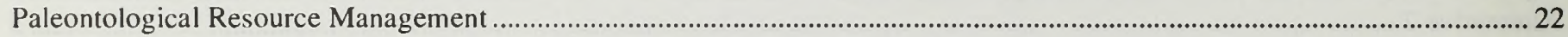

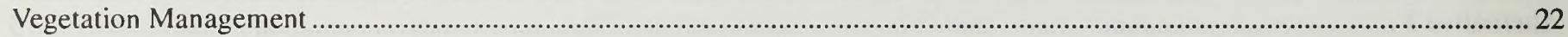

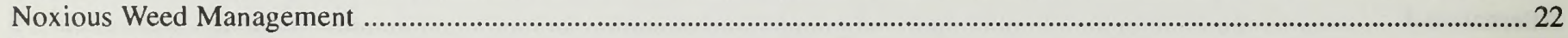

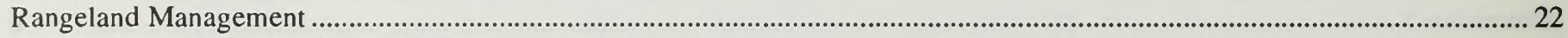

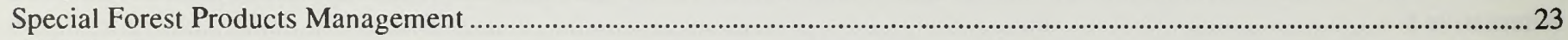

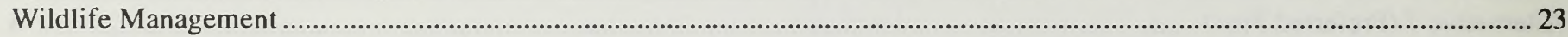

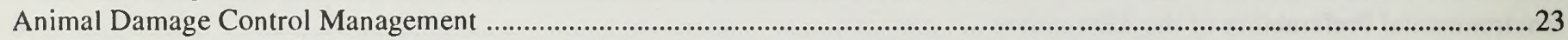

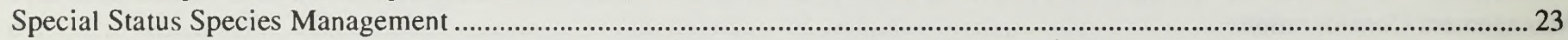

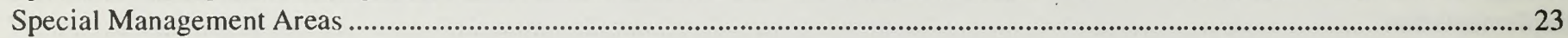

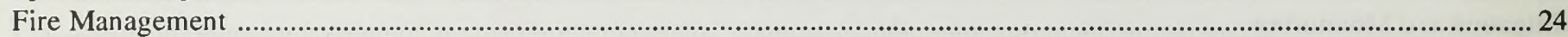

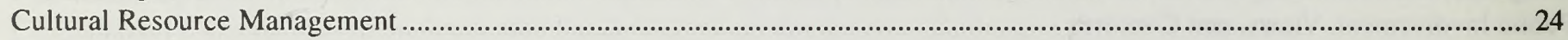

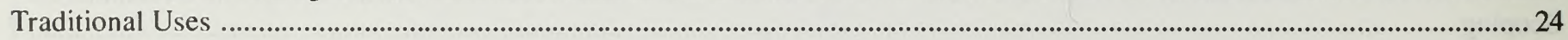

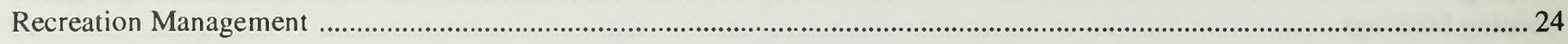

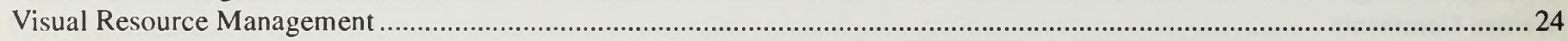

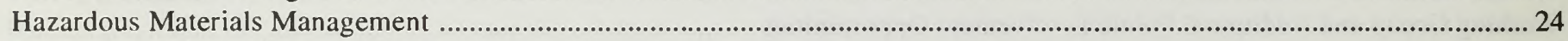

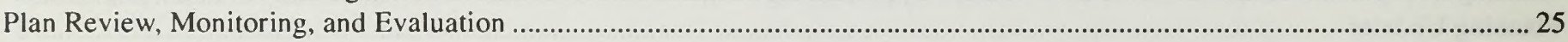

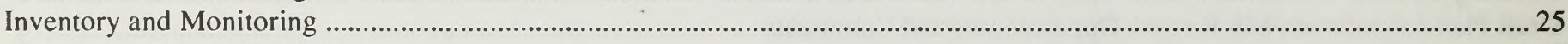

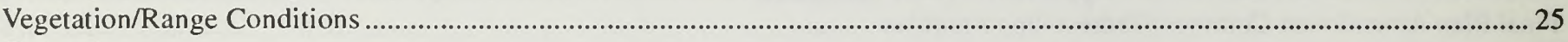

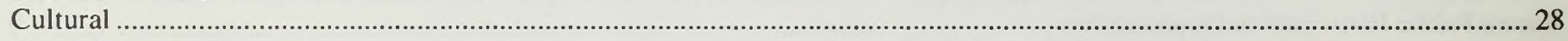

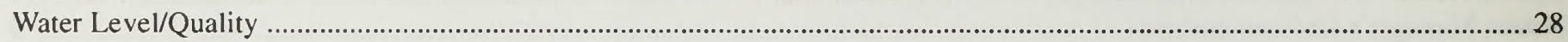

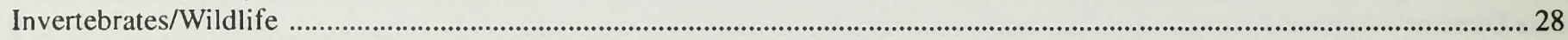

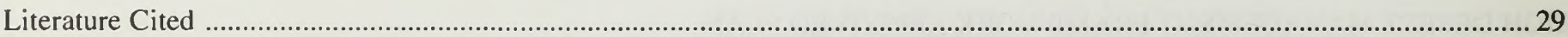

\section{LIST OF FIGURES}

Figure No. Title

Page No.

1.

2.

3.

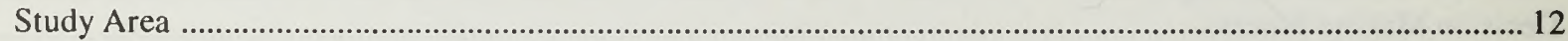

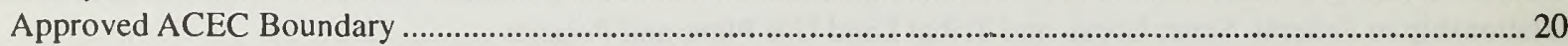

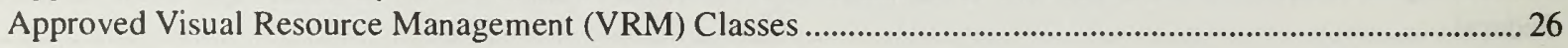


Record of Decision for the High Desert

Management Framework Plan Amendment for the Lake Abert Area of Critical Environmental Concern (ACEC) In Lake County, Oregon

Prepared by the Bureau of Land

Management, Lakeview Resource Area Office, Lakeview District

\section{Decision}

In response to the requests from the Oregon Department of Fish and Wildlife and Oregon Waterfowl and Wetlands Association (letters dated August 1992) to consider designation of Lake Abert and the surrounding area as an Area of Critical Environmental Concern (ACEC), the findings of the Bureau of Land Management (BLM), Lakeview District that it meets the criteria for designation as an ACEC (BLM, 1993), public/agency comments received on the proposal to designate the area as an ACEC, and on the basis of the analysis contained in Draft Plan Amendment/EIS (BLM, 1995c) and the Proposed Plan Amendment/Final EIS (BLM, 1996), I have decided to designate approximately 49,900 acres of lands administered by the BLM, Lakeview District, as an ACEC. Special management direction shall be provided for this area as highlighted in the attached Approved Plan Amendment. The planning area included approximately 123,000 of BLM-administered land located in central Lake County, Oregon. The boundary of the ACEC is established as the top of Abert Rim on the east, the edge of the boundary of a right-of-way for an existing powerline on the northeast, an existing county road and private property lines on the north, and an existing jeep trail on the northwest, a new 3.5-mile riparian exclosure fence on the west, and legal/property lines on the southwest as shown in Figure 2 of the attached Approved Plan Amendment. The ACEC includes the BLM-administered portions of the lake, most of the the surrounding archaeological sites/district, part of the Abert Rim wilderness study area (WSA), and the playa on the north end of the lake. In addition, visual resource management classifications have been changed throughout the entire planning area. Designations will become effective on the date that the notice of this decision appears in the Federal Register.

\section{Alternatives, Including the Proposed Action}

\begin{abstract}
A number of alternatives were considered for evaluation during the plan amendment process. Several were eliminated from further study. These included ACEC designation with no change in existing management, designation of the entire watershed as an ACEC, termination of all livestock grazing within the area, and designation as a wilderness area rather than as aCEC. A brief description of these alternatives and the reasons for their elimination from further study is contained in the Draft Plan Amendment/Environmental Impact Statement (EIS). Seven alternatives were considered for detailed analysis. These are summarized below. A more detailed description of the alternatives can be found in the draft and final documents.
\end{abstract}

\section{Alternative 1 (No Action - Continue Existing Management)}

This alternative consists of continuing current management practices within the study area (approximately 99,900 acres of BLM-administered lands out of a total of about 123,000 acres) in accordance with the High Desert Management Framework Plan, Lakeview Grazing Management Final Environmental Impact Statement (BLM, 1983; 1981), other programmatic and activity level plans (BLM, 1989a; 1989b; 1994b), and current BLM policies and directives. The area would not be designated as an ACEC. No special management would be implemented.

\section{Alternative 2}

Under this alternative, the entire Lake Abert drainage (approximately 99,900 acres of BLM-administered lands out of a total of about 123,000 acres) would be designated as an $\mathrm{ACEC}$ and very restrictive management would be implemented. This is considered to be the environmentally preferable alternative as defined by 40 CFR Part 1505.2(b).

\section{Alternative 3}

Under this alternative, a portion of the planning area (approximately 31,600 acres of BLM-administered lands) would be designated as an ACEC with some special management actions implemented.

\section{Alternative 4}

A portion of the study area (approximately 39,300 acres of BLM-administered lands) would be designated as an ACEC under this alternative with some special management actions implemented. 


\section{Alternative 5}

Under this alternative, a portion of the planning area (approximately 42,100 acres of BLM-administered lands) would be designated as an ACEC with some special management actions implemented.

\section{Alternative 6}

Under this alternative, no ACEC designation would occur. The area would be managed similar to alternative 1 , but minor changes in existing management would occur in the area of minerals, aquatic communities, cultural resources, and recreation.

\section{Alternative 7 (Preferred Plan)}

Under this alternative, a portion of the planning area (approximately 49,900 acres of BLM-administered lands) would be designated as an ACEC with some special management actions applied. This represents the BLM's preferred plan and is similar to Alternative 5 in most respects with the exception of management of minerals, special management areas, and visual resources.

\section{Environmental Peferability of the Alternatives}

Environmental preferability is judged using the criteria in the National Environmental Policy Act (NEPA) and subsequent guidance by the Council on Environmental Quality (CEQ, 1981). The CEQ has defined the environmentally preferable alternative is that alternative that will promote the national environmental policy as expressed in Section 101 of NEPA. This section lists six broad policy goals for all Federal plans, programs, and policies:

1) fulfill the responsibilities of each generation as trustee of the environment for succeeding generations;

2) assure for all Americans safe, healthful, productive, and esthetically and culturally pleasing surroundings;

3) attain the widest range of beneficial uses of the environment without degradation, risk to health or safety, or other undesireable and unintended consequences;

4) preserve important historic, cultural, and natural aspects of our national heritage, and maintain, wherever possible, an environment which supports diversity and variety of individual choice;

5) achieve a balance between population and resource use which will permit high standards of living and a wide sharing of life's amenities; and
6) enhance the quality of renewable resources and approach the maximum attainable recycling of depletable resources.

Based on these criteria, identification of the most "environmentally preferable" alternative involves a balancing of current and potential resource uses with protection. Alternatives 1 and 6 would generally be the least environmentally protective and offer the most unrestricted use of the area. Alternative 2 would be more environmentally protective than any of the other alternatives, it would offer fewer "beneficial uses" or achieve less of a "balance between population and resource use". The environmental analysis contained in the Draft and Final Environmental Impact Statements (EIS's) shows Alternatives 3-5 are about equal in terms of environmental protection and "environmental preferability". [See FEIS Tables S-1 and S-

2.] Alternatives 3-5 fall somewhere in between the least (Alternatives 1 and 6 ) and most (Alternative 2) environmentally protective alternatives, but, if environmental protection is considered the overriding goal, they are less environmentally preferable than Alternative 2 . Alternative 7 , which is the approved plan amendment and Area of Critical Environmental Concern plan, allows for potential sodium extraction and other beneficial resource use or extraction similar to Alternatives 3-5, but offers slightly more protection to the lake, shoreline and upland resource values and ecosystem functions than Alternatives $1,3,4,5$, or 6 . Aquatic ecology, cultural resources, visual resources and wildlife habitat impacts would be minimized or mitigated through management actions and permit, lease or use restrictions. Given the need to balance the six CEQ goals, the BLM finds that Alternative 7 is the environmentally preferred alternative.

\section{Management Considerations}

In response to two separate nominations, the Lakeview District evaluated Lake Abert and the surrounding area as a potential ACEC and found it met the criteria found in 43 CFR 1610.7-2 (BLM, 1993). Since the existing land use plan failed to consider the area's potential as an ACEC (BLM, 1983), the BLM intiated the plan amendment process to address three specific questions: 1) should the area be designated as an ACEC, if so, 2) how large an area should be considered for ACEC designation and, 3) what special management actions were needed to protect the relevant/ important resource values(wildlife, aquatic ecology, archaeology, and visual)?

Extensive public input was sought during the plan amendment process. Based on the input received, there was wide public support and opposition to the proposed ACEC designation, boundary locations, and special management 
actions. Through this process, it was apparent many were confused over the differences between ACEC and wilderness management. Since no formal comments were received from other Federal, state, or local agencies or tribal governments stating that the proposal conflicted with their existing plans or policies, the BLM assumes the Approved Plan Amendment is consistent with such existing plans and policies.

The BLM is tasked with the difficult job of multiple use management as mandated under the Federal Land Policy and Management Act and numerous other conflicting laws and regulations which govern the management of public lands. The Approved Plan Amendment (attached) attempts to provide a balance between those reasonable protective measures necessary to protect the resource values for which ACEC designation was being considered with the continued public needs to use the area and, thereby, comply with applicable laws, regulations, policy, and agency direction.

\section{Implementation}

Though designation of the ACEC (and the special management direction contained within in the attached Approved Plan Amendment) will become effective on the date that the notice of this decision appears in the Federal Register, the implemention of the attached Approved Plan Amendment will require implementation over a number of years. The actual rate of implementation will be tied to the BLM's budget process. Priorities for management are developed through long-term budgeting processes and in consultation with other agencies, tribes, and government bodies. Some actions may require the preparation of separate National Environmental Policy Act (NEPA) analysis/documentaion (including publication of a separate decision document) prior to implementation while others may be adequately addressed within the draft and final environmental impact statements associated with this Record of Decision and require no additional documentation prior to implementation. Implementation progress will be reported annually in the Lakeview District's Planning Update.

\section{Mitigation and Monitoring}

All protective measures and other management direction identified in the attached Approved Plan Amendment will be taken to avoid or mitgate adverse impacts throughout the plan implementation. All practical means to avoid or reduce environmental harm will be adopted, monitored, periodically evaluated, as appropriate. Monitoring will be conducted as identified in the Approved Plan Amendment. Monitoring and periodic plan evaluations will be used to ensure that the plan is being implemented, progress is being made towards meeting the plan goals and objectives, that mitigation is proving effective, and the plan is being maintained consistent with current BLM policy.

\section{Public Involvement, Views, and Concerns}

\section{Scoping}

At the beginning of the plan amendment process input was sought through public scoping. A scoping document discussing the ACEC nomination proposal was prepared and circulated to all individuals, groups, agencies, and Native American groups with a known interest in ACEC's or general management activities within the Lakeview Resource Area (several hundred). The scoping document was released on January 7, 1994, and was followed by about a 45-day comment period. The scoping period was announced through notices and/or feature stories in the Federal Register (58 (244) FR 67806), the Lake County Examiner (Lakeview), the Herald and News (Klamath Falls), and the Bulletin (Bend) in December 1993.

\section{Scoping Meetings}

During the scoping period, two public scoping meetings were held in February 1994, one in Lakeview and one in Bend. A total of eighteen people attended the Lakeview scoping meeting, not including approximately 10 BLM staff. A total of 12 people attended the Bend scoping meeting, not including $7 \mathrm{BLM}$ staff. Notes documenting the major issues and concerns raised during the scoping meetings are contained in the planning file.

\section{Written Comments}

During the scoping period, 103 comment letters were received and considered. After the close of the scoping period, two additional letters were received and also considered. Seventy-two consisted of a form letter sent by primarily local residents, ranchers, and representatives of local business and industry who were generally opposed to the proposed ACEC designation. Ten other letters were generally in opposition to the proposal. Nineteen letters from other agencies, environmental groups, concerned citizens, and scientific researchers were generally in favor of designation and/or some form of protection for the area. Two were from agencies that expressed neither opposition nor favor of the proposal. One had no comments. Several 
respondents provided copies of recent scientific publications on the lake ecosystem or pertinent data on resources found in the vicinity. One respondent provided a history of the Mono Lake, California ACEC designation experience which utilized a working group.

The comments were examined and categorized under one of several general headings: ACEC Nomination is Unnecessary, Nomination Will Result in Limitations on Use, Land/Mineral Ownership, Flaws in the Nomination Proposals, Existing Conditions of the Lake Ecosystem, Perceived Area Problems, Alternatives/Issues Which Should Be Addressed in the Planning Process, and Alternative Boundaries. A complete summary of the public comments received during the scoping period is contained in the planning file. These comments and concerns were used to develop the list of issues, goals, objectives, and alternatives discussed in the Draft and Final Plan Amendment/EIS documents.

\section{Working Group and Additional Public Involvement Opportunities}

A letter was sent out to everyone on the mailing list (over 300 ) inviting their participation on an informal working group (letter dated March 2, 1994) intended to provide other agencies, tribal governments, groups, and the general public with additional opportunities to provide input into the planning process. Approximately 35 people responded with an interest in this opportunity and were subsequently sent a packet of information for review prior to the first meeting (letter dated April 4, 1994). A total of 6 working group meetings were held between April 1994, and February 1995. Though attendance at these meeting varied, a total of thirtyfour individuals, representing state and county governments, tribal interests, concerned citizens, ranchers, hydro power proponents, brine shrimp fishery, area recreationists, environmentalists, and researchers. All meetings were open to the public and were announced through news releases in local newspapers prior to the meeting date. Copies of all meeting notices, mailings, handouts, lists of attenders, and minutes are contained in the planning file.

\section{Planning Updates}

During the time between the end of the formal scoping period and the completion of this Draft Plan Amendment EIS, all those on the mailing list were sent project updates (letters dated June 10 and September 22, 1994) and were invited to participate in these public meetings and provide feedback. Many written comments were received. A summary of these comments and corresponding responses are contained in the planning file. These comments were incorporated or addressed within the draft document to the extent possible. In addition, the March 1994 and May 1995 Planning Updates and October 1994 Fremont Frequent Flyer provided and plan process updates and notification of public participation opportunities.

\section{Draft Plan Amendment/EIS Review Opportunities and Comments}

The draft document was made available for 90-day public review period which ended on August 16, 1995. Public review/comment opportunities were announced in Federal Register notices published on May 10 and 19, 1995, as well as legal notices/news releases that appeared in the Lake County Examiner, the Klamath Falls Herald and News, and the BLM News between May and July 1995.

A total of 37 written comment letters were received on the draft document. Five of these letters were from individuals conducting research in the area who wished to provide additional data/information, correct misinterpretation of existing data presented in the analysis, and/or support for ACEC designation. Twenty-six letters were from environmental groups or individuals supporting adoption of Alternative 2 along with 2-5 of the same general recommended changes in that alternative. One letter was from a representative of the brine shrimp industry generally in support of ACEC designation, but also expressed concern over the perceived failure of the BLM to address future water allocation in the basin. Three letters were from Federal or state agencies. Two letters were from individuals expressing support for adoption of Alternative 7. The complete collection of comment letters received and the BLM's response are contained in Appendix A of the Proposed Plan Amendment/Final Environmental Impact Statement. Those comments which were considered substantive were incorporated/addressed in this final document.

Two public meetings were held during this review period which were also announced in the legal notices/newspaper releases described above and in the draft document cover letter. The first, held in Lakeview, Oregon, had a total of 14 members of the public in attendance and served mainly as an opportunity to answer questions on the draft document analysis. The second meeting held in Bend, Oregon, failed to draw any public interest. Copies of meeting notes are available as part of the planning record.

\section{Final Plan Amendment Comment/Protest Opportunities}

A 30-day public review/protest period was provided on the final document. Two comment letters were received during this period; one from a researcher actively involved in research on the lake who was generally in favor of ACEC designation, but had questions related to monitoring requirements and one from a local citizen generally opposed to ACEC designation and taking issue with much of the document. These comments letters were responded to 
individually. A third letter was received requesting a copy of the final document, which was sent. Several telephone conversations occurred between BLM staff and two separate individuals which were considering protesting the Proposed Plan Amendment/Final EIS. A fourth letter was received which officially protested four separate issues of the proposed plan, but not the actual ACEC designation. This letter was signed by an individual and two representatives of area environmental groups. A fifth letter was received from one of the protesting parties after the close of the protest period as a follow up to the protest letter. The protest was resolved via a letter from the BLM Director to the protesting parties in July 1996.

Future Public Participation Opportunities

Some actions may require the preparation of separate (project level) National Environmental Policy Act (NEPA) analysis/documentaion prior to implementation. This would include an opportunity for public comment and protest/ appeal prior to the preparation of a separate decision document. The public will be made available of additional participation opportunities through the publication of the Lakeview District's annual Planning Update and notices in local newspapers. However, some management actions which have been adequately addressed within the Draft/Final EIS's may be implemented without additional NEPA documentation or public participation opportunities. Implementation of such actions will also be reported in the Planning Update.

District Manager's Recommendation

With the full knowledge of the commitments being made, I recommend the adoption of this Record of Decision and the attached High Desert Management Framework Plan Amendment for the Lake Ibert Area of Critical Environmental Concern (ACEC) in Lake County, Oregon.
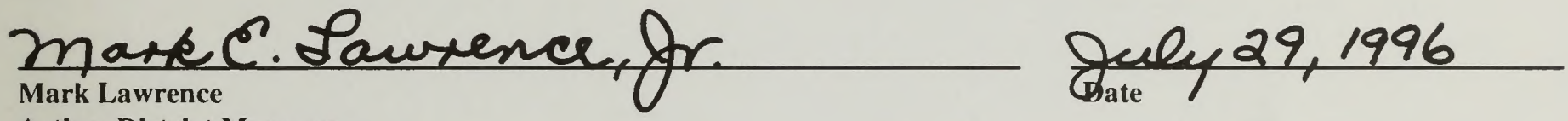

Acting, District Manager

Lakeview District

State Director's Approval

I concur with the District Manager's recommendation and find that this document meets the requirements for a Record of Decision as specified in 40 CFR Part 1505.2. I hereby approve this Record of Decision and the attached High Desert Management Framework Plan Amendment for the Lake Abet Area of Critical Environmental Concern (ACEC) in Lake County, Oregon, effective on the date that notice of this decision appears in the Federal Register.

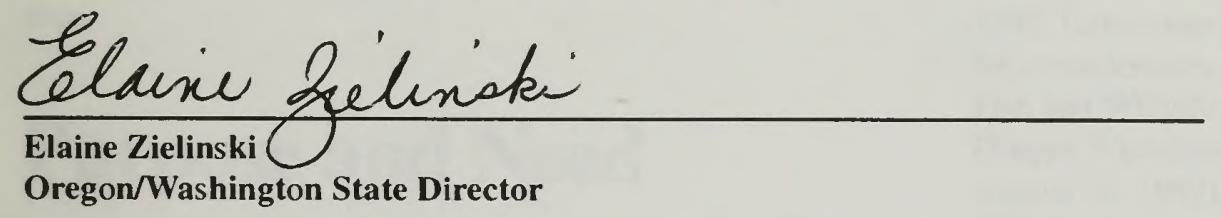

AUG 121996

Date

9 



\section{High Desert Management Framework Approved Plan Amendment for the Lake Abert Area of Critical Environmental Concern (ACEC) In Lake County, Oregon}

\section{Planning Area}

The planning area is located approximately three miles northeast of Valley Falls in central Lake County, Oregon (Figure 1) within the Lakeview Resource Area (formerly called the High Desert Resource Area) and consists of approximately 188 square miles of Lake Abert and the surrounding area. The planning area includes private, state, and BLM-administered lands. Abert Rim Wilderness Study Area (WSA) is located along the eastern edge of the planning area.

\section{Purpose and Need}

The Lakeview District of the Bureau of Land Management (BLM) has prepared this plan amendment to address the appropriateness of designating Lake Abert and the surrounding area as an Area of Critical Environmental Concern (ACEC). This designation (accompanied by special management actions) has been evaluated as a means of protecting significant resources in the area.

Section 202 of the Federal Land Policy Management Act (FLPMA) states, "in the development of land use plans, the Secretary shall give priority to the designation and protection of Areas of Critical Environmental Concern" (ACEC). The Bureau of Land Management (BLM) regulations define an $\mathrm{ACEC}$ as an area "within the public lands where special management attention is required (when such areas are developed or used or where no development is required) to protect and prevent irreparable damage to important historic, cultural, or scenic values, fish and wildlife resources, or other natural systems or processes, or to protect life and safety from natural hazards". The FLPMA and BLM regulations allow potential ACECs to be nominated by staff, other agencies, or members of the public at any time. In 1992, Lake Abert and the adjacent uplands were nominated for consideration as an ACEC by the Oregon Department of Fish and Wildlife (letter dated August 7, 1992) and the Oregon Waterfowl and Wetlands Association (letter dated August 10, 1992).

Current land use management activities for the Lakeview Resource Area (which contains the planning area) are guided by the High Desert Management Framework Plan (MFP) completed in 1983 (BLM, 1983). However, this MFP did not evaluate the Lake Abert area as a potential Area of Critical Environmental Concern (ACEC). The BLM has since recognized four important resource values or processes in the Lake Abert area potentially deserving special management attention: wildlife resources, cultural resources, scenic values, and ecological processes (BLM, 1993). ACEC designation recognizes the area possesses significant values 

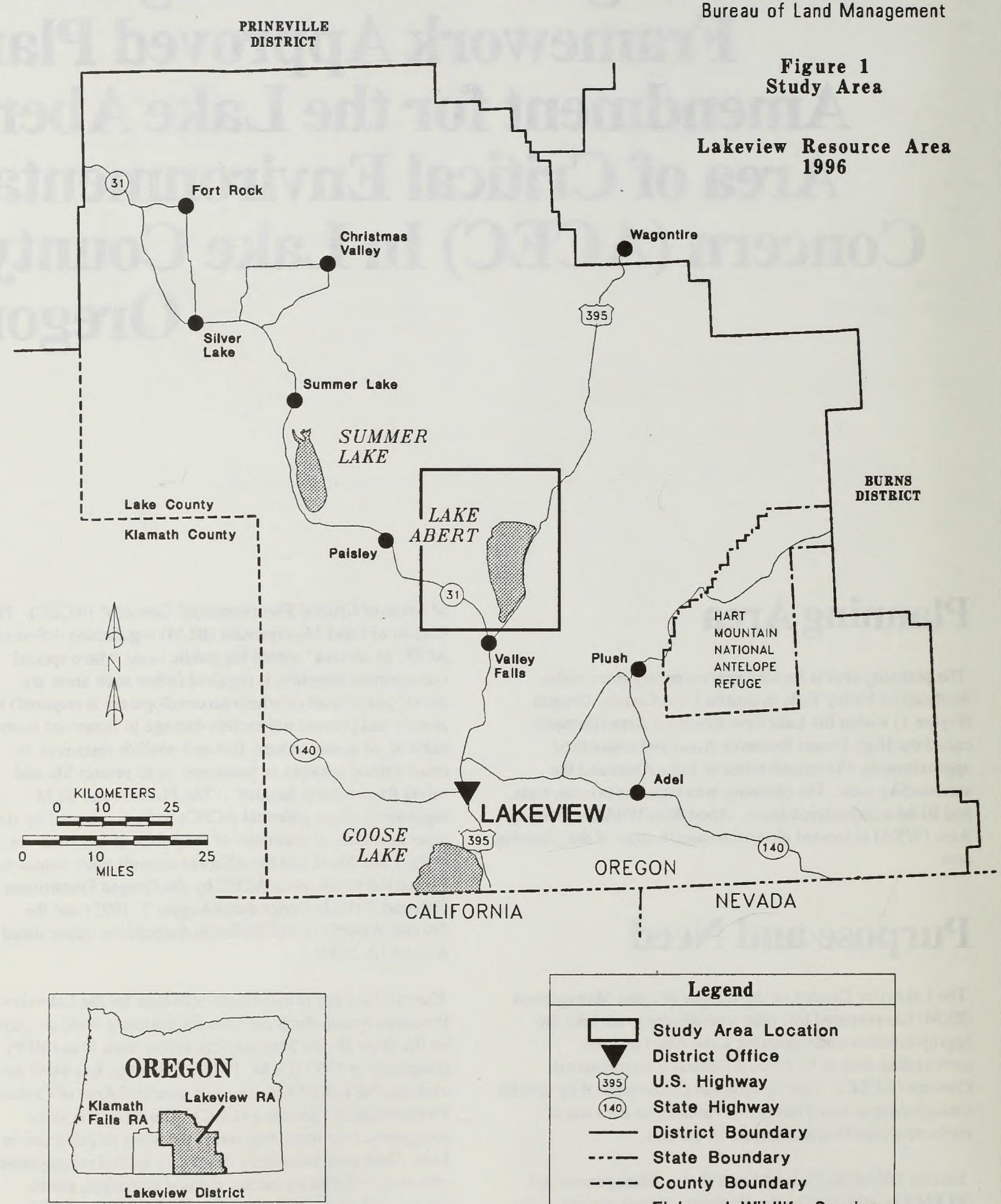

\begin{tabular}{|l|}
\hline \multicolumn{1}{|c|}{ Legend } \\
\hline$\square$ Study Area Location \\
District Office \\
U.S. Highway \\
State Highway \\
\hline 140 - District Boundary \\
$-\ldots-$ State Boundary \\
--- County Boundary \\
$---\begin{array}{l}\text { Fish and Widdife Service } \\
\text { Boundary }\end{array}$ \\
\hline
\end{tabular}


and establishes special management measures to protect those values. Designation helps assure that the significant values or resources are adequately addressed in future management actions and land use proposals within the area.

\section{Planning Process}

The plan amendment/ACEC planning process is defined in Federal regulations (43 CFR Part 1610) and was discussed in detail in the draft document and will not be repeated here. To be designated as an ACEC, an area must be evaluated and found to meet both relevance and importance criteria for at least one resource value (43 CFR 1610.7-2). The Lake Abert area was evaluated with respect to these criteria (BLM, 1993). The results are summarized in the following section.

\section{ACEC Evaluation Findings}

During the nomination process prehistoric cultural, wildlife, unique natural system (aquatic ecology) and scenic values in and around Lake Abert were identified as reasons for ACEC designation. After careful consideration of these and other potential values, the BLM interdisciplinary team evaluated these four values in detail. The staff prepared several resource inventory reports and combined the information into a summary report. The report documents that Lake Abert and its immediate surroundings meet the relevance and importance criteria for the presence of: prehistoric cultural values, scenic values, wildlife (both populations and habitat) resources, and natural processes (aquatic ecology). The natural hazards (landslides, rockslides, cliffs and potential for flash flooding) which are present were found to meet the relevance, but not the importance criteria (BLM, 1993).

\section{Decision Making Process}

Prior to making a decision to designate the area as an ACEC, a Draft and Final Plan Amendment/EIS were prepared (BLM, 1995c; 1996). These documents analyzed the environmental impacts of designating/managing the area as an ACEC, identified special management practices needed, uses to be allowed, and mitigation measures. In preparing the Approved Plan Amendment/ROD, the District Manager is recommending that the State Director approve/ sign the plan amendment. All protests must be resolved prior to the State Director approving the plan amendment. Signing of the ROD constitutes official ACEC designation for the area and plan amendment approval.

\section{Relationship to Federal, State, Local, and Tribal Land Use Plans and Policies}

In the Draft Plan Amendment/EIS, the BLM documented the consistency of the proposed ACEC designation and management activities with the existing, known Federal, State, Local, and Tribal land use plans/policies. An additional regional scale plan was released during the public review period by the Ore-Cal Resource Conservation and Development Council (1995) which was considered.

Appropriate agencies, state and local governments, and tribes were given an opportunity to comment on consistency with their plans/policies during the 90 -day review period. The National Park Service, U.S. Environmental Protection Agency, Federal Energy and Regulatory Commission, Oregon Division of State Lands, and Oregon Department of Fish and Wildlife were the only agencies that provided written comments on the documents, though the Bureau of Mines did also comment on the proposal during the scoping phase. The Governor of Oregon was provided an opportunity to review and comment on both the draft and final documents. No comments were received from the Governor nor were were any comments directly related to plan consistency received from other agencies or tribal governments. Therefore, the BLM assumes there are no major concerns with plan consistency other than those disclosed in the draft document. The reader should refer to the draft plan amendment/EIS for this discussion.

\section{Federal}

A number of land use or resource management plans have been developed by the BLM and other Federal agencies which relate to or otherwise govern how management is carried out within the planning area. The BLM is responsible for determining if the proposed plan amendment is in conformance with these plans. The following Federal plans have been identified as applicable to the planning area and, unless otherwise noted, are believed to be in conformance with the proposed plan amendment. Where appropriate, the management direction and previous management decisions set forth by these documents, and the impacts outlined therein, are used to tier analyses performed in this plan amendment, or are incorporated by reference, and therefore, are not repeated in detail within this plan amendment. Therefore, pertinent decisions already established by these documents are not being revisted here, but are merely mentioned to give the reader a broad perspective of all management activities occuring within the planning area. 
* High Desert Management Framework Plan (BLM, 1983) - not in conformance with respect to ACEC evaluation, thus requiring the proposed plan amendment.

* Lakeview Grazing Management Final Environmental Impact Statement (BLM, 1982b) and Record of Decision - in conformance with respect to grazing administration, but did not consider ACEC designation.

* Range Reform '94 Final Environmental Impact Statement (BLM and Forest Service, 1994) and Record of Decision - this national level plan amends current grazing administration and management practices. It established 15 member Resource Advisory Councils (RAC) to develop regional standards and guidelines related to grazing practices and make recommendations on management of local Federallyadministered lands. Should the RAC fail to develop regional standards and guidelines within 18 months of the decision, default national level standards will become effective.

* Wilderness Studies Management Framework Plan Amendments (BLM, 1982a) - amended the High Desert Management Framework Plan with respect to wilderness issues due to the completion of a state-wide wilderness inventory. The most pertinent section discusses alternative boundary designation for the Abert Rim wilderness study area (WSA). This document led to the Oregon Wilderness Final Environmental Impact Statement (BLM, 1989a), Wilderness Study Report, and Record of Decision (BLM, 1991a) which evaluated the impacts of and recommended to Congress designation of certain wilderness areas within the State of Oregon, including designating 23,760 acres on Abert Rim as wilderness.

* Wilderness Interim Management Policy (IMP) (BLM, 1987b) - national level policy covering the interim management of wilderness study areas, pending final designation action by Congress.

\section{* Weed Management Plan for the Lake Abert Area} (BLM, 1995b) - site-specific draft plan developed to address continued weed expansion in the Lake Abert area. The plan is tiered to the Integrated Noxious Weed Control Program Environmental Assessment (OR-013-93-03), Lakeview Reesource Area (BLM, 1994). This Environmental Assessment (OR-013-9303) covers the environmental impacts of conducting an integrated noxious weed control plan throughout the Lakeview Resource Area. Of particular relevance to this plan amendment are known weed infestations around Lake Abert which have been treated unsuccessfully with a biological control agent over the past several years. The decision resulting from the EA is currently under appeal, however, a request for a stay of the action was denied by the Interior Board of Land Appeals. This document is, in turn, tiered to the following three documents: Vegetation Treatment on BLM Lands in Thirteen Western States Final Environmental Impact Statement (BLM, 1991b), Northwest Area Noxious Weed Control Program Final Environmental Impact Statement (BLM, 1985), Supplement to the Northwest Area Noxious Weed Control Program Final Environmental Impact Statement.(BLM, 1987a).

* Site-Specific Environmental Assessment Tiered to the 1987 Final Environmental Impact Statement for Rangeland Grasshopper Cooperative Management Program (Animal and Plant Health Inspection Service (APHIS), 1995b) - covers the periodic need to control grasshopper outbreaks in various rangeland and agricultural areas within Lake County, including the general vicinity of Lake Abert. The lead for this type of action rests with APHIS, but the BLM does cooperate when treatment involves lands under its administration. This Environmental Assessment is, in turn, tiered to the Rangeland Grasshopper Cooperative Management Program Final Environmental Impact Statement (APHIS, 1987).

* Wildlife Damage Management in the Roseburg ADC District in Southwestern Oregon Environmental Assessment and Record of Decision (APHIS, 1995a) covers wildlife damage management activities in the Lakeview Resource Area, including the Lake Abert area. APHIS is the lead agency for this action. The BLM served as a cooperating agency in the preparation of this Environmental Assessment. This Environmental Assessment is tiered to the Animal Damage Control Final Environmental Impact Statement and Record of Decision (APHIS, 1994).

* Mineral Disposal Pit Environmental Assessments (BLM, 1978a; 1978b) - assessed the environmental impacts of development and operation of two small (less than 40 acres) gravel pits in the vicinity of Lake Abert which are still in operation today.

* Riparian Exclosure Fence Environmental Assessment (BLM, 1995a) - assessed the environmental impacts of a riparian exclosure fence (approximately 3.5 miles in length) along the western shore of Lake Abert.

Appropriate Federal agencies were provided with an opportunity to review the proposed plan amendment and provide comments on its consistency with their plans, policies, and directives. In addition to the plans listed above, one other initiatives is currently underway that may eventually amend certain management directions within this plan amendment. Though it would first appear more logical 
to wait until such initiatives are completed prior to making a decision on this plan amendment, the BLM can not simply stop managing or proposing appropriate changes in management for lands under its jurisdiction until such planning efforts are completed (which is likely to be several years into the future). This initiative includes:

* Columbia Basin Ecosystem Management Project regional ecosystem-based inter-agency planning effort currently in progress for parts of the States of Oregon, Washington, Idaho, and Montana. Products from this effort will include a scientific assessment of existing conditions and trends within the entire basin and two Environmental Impact Statements. A draft Environmental Impact Statement covering Oregon and Washington east of the Cascade Mountains is expected late in summer of 1996.

\section{State}

The State of Oregon uses “Oregon's Statewide Planning Goals" to guide land use planning within the state (Department of Land Conservation and Development, 1994). This requires local governments to develop their own comprehensive plans which are consistent with, and implement on the local level, the state's goals. One other document which is applicable to the study area is the "Oregon Natural Heritage Plan" (Natural Heritage Advisory Council to the State Land Board, 1993). The Governor and various agencies within the State of Oregon were given an opportunity to review the Draft and Proposed Plan Amendment/EIS's and comment on consistency with their goals, policies, and plans. No comments or objections were received from the Governor, nor were any comments received from state agencies directly related to consistency with existing state plans, policies, or goals.

\section{Lake County}

Lake County has an existing comprehensive land use plan developed in response to the State of Oregon's requirement for local governments to develop land use plans. The plan consists of a number of reports, ordinances, and subsequent amendments governing land use practices and policies within the county (Lake County, 1979; 1983; 1989a; 1989b; 1989c; 1992).

The plan classifies the lands surrounding the lake as rangelands. The open space inventory within the "Lake County Atlas" (Lake County, 1979) recognizes the area along the northwest shore of the lake as critical deer and antelope habitat. The southeast shore is recognized as critical deer habitat. It further states that "one of the primary functions of the County Plan is to identify and recognize natural areas" (page 96) and lists Abert Lake and Rim as one of many recognized research and potential natural areas found within the county (page 97).

The atlas was amended in 1983 (Lake County, 1983) and recognized Abert Rim's wilderness study area status (page 18 ) and value as a scenic corridor (page 19). The wildlife habitat map recognized additional portions of the area as valuable wildlife habitats (deer and antelope range; wetlands). The revised open space map shows Lake Abert proper as a designated natural area.

In 1992, the county passed an "Emergency Ordinance and Interim Public Land Management Plan" (Lake County, 1992) to supplement the existing land use plan, as amended. This ordinance does not support the designation of any additional wilderness areas, roadless areas, or research natural areas within the county. Though it does not specifically discuss ACEC designation, its intent was to discourage any more special area designations. The ordinance encourages exploration and development of mineral/energy resources within the county, continuing of livestock grazing/ agricultural uses at historic levels consistent with sound management practices, as well as continuing the control of predatory animals and noxious weeds.

Although ACEC designation is inconsistent with the intent of the 1992 ordinance regarding special area designation, the managment direction of the Approved Plan Amendment does not preclude any of the above mentioned management activities, provided they meet the plan goals and objectives. The Lake County Commissioners were provided with an opportunity to review the proposed plan amendment and comment on its consistency with their approved plans and policies. No formal comments related to consistency with the county plan were received.

\section{Tribal Governments}

Four recognized tribal governments are known to have an interest in the Lakeview Resource Area: the Klamath Tribes, Confederated Tribes of the Warm Springs Reservation, Burns Paiute Tribe, and Fort Bidwell Tribe. It is unknown if any of these government bodies have a formal land, resource, or economic development plan which would be consistent or in conflict with the proposed plan amendment. However, the Klamath Tribes are known to have a policy calling for no surface disturbance of their ceded lands. These tribal governments have been given several opportunities to participate in the preparation of this plan, review the plan, and provide a consistency determination. No formal comments were received. 


\section{Management Goals and Objectives}

Ten general management goals for the study area were developed along with a number of more specific objectives to aid in measuring, over time, how well an alternative meets the goals. The following goals and objectives were developed to address the issues and concerns raised during the public involvement process. They are not listed in any order of priority and, at first glance, may be some that appear to be in direct conflict with each other. This reflects the various legal mandates under which the BLM operates. While some goals may conflict, they are not totally exclusive of each other. The alternatives that were developed and analyzed emphasized some goals over others.

Inventory and monitoring are needed to determine if certain goals and objectives of the Approved Plan Amendment are being met. However, not all goals and objectives require inventory and monitoring to determine this. Those goals/ objectives requiring inventory/monitoring are indicated in the following discussion. A more detailed discussion of the plan inventory and monitoring requirements is included on pages 25 and 28 .

\section{Goal 1}

Maintain a viable, sustainable ecosystem within the lake and surrounding area (prevent changes that would cause significant, adverse effects on ecological values).

\section{Objectives}

a) Maintain current aquatic and wetland plant community diversity by not allowing any future, human-caused activity that would cause a significant change (defined as a $10 \%$ human-caused change over any three-year period at an $85 \%$ confidence level) in relative species abundance. Should a significant change occur, existing management would be reevaluated. Monitoring would occur as described on pages 25 and 28.

b) Authorize no future discretionary human action which will increase the number of years by more than $5 \%$, when compared to the 1926-1994 baseline, that the average total dissolved solid concentration in Lake Abert exceeds 100 grams per liter $(\mathrm{g} / \mathrm{l})$ or reduces the level of the lake below 4,251 feet in elevation. (Note: water chemistry changes, primarily the ratio of dissolved carbonates to chlorides, are not addressed by this objective and would require detailed evaluation in a separate, project-specific NEPA document which would include a model of other criteria to be developed at a future date). Monitoring would occur as described on page 28 .

\section{Goal 2}

Maintain or enhance economic conditions consistent with other listed goals and existing laws, regulations, and policies.

\section{Goal 3}

Maintain or enhance existing resource values for future generations (i.e. do not exclude future options by current management actions).

\section{Goal 4}

Continue current, traditional, and historic land and resource uses in the area.

\section{Goal 5}

Maintain or enhance recreational opportunities and wilderness values.

\section{Objectives}

a) Manage the area in accordance with the following Recreation Opportunity Spectrum (ROS) management objectives with the intent of allowing continuation of hunting, limited trail development, and other recreation opportunities within the area:

* Preserve primitive, non-motorized recreation opportunities east of Highway 395 (within Abert Rim WSA).

* Manage the Highway 395 corridor as a Roaded

Natural Environment.

* Manage the playa at the north end of the lake and the westside of the lake as a Semi-Primitive, Motorized area.

b) Manage Abert Rim WSA in accordance with the Wilderness Interim Management Policy (BLM, 1987b) until a final decision on wilderness designation is made by Congress. The Wilderness IMP generally precludes activities which permanently impair existing wilderness values.

\section{Goal 6}

Maintain the present visual/aesthetic quality. 


\section{Objectives}

a) Allow no developments which would cause a significant, adverse visual impact to the casual observer as viewed from the primary travel corridor of Highway 395.

\section{Goal 7}

Protect and/or interpret, where appropriate, existing cultural resource values, including protecting and respecting Native American traditional uses.

\section{Objectives}

a) Ensure that, in any given year, no cultural sites are damaged due to unauthorized excavation. Monitoring would occur as described on page 28.

\section{Goal 8}

Maintain or enhance habitat quality and quantity for native plant and animal species, including special status species (such that the latter do not become Federally-listed).

\section{Objectives}

a) Provide or maintain an upland vegetation community (composition by weight of total annual production) of $70-80 \%$ grasses, $5-15 \%$ forbs, and 5$15 \%$ shrubs, on existing seeded areas. Monitoring would occur as described on pages 25 and 28 .

b) Provide or maintain an upland native vegetation community (composition by weight of total annual production) of 30-40\% grasses, 5-15\% forbs, and 25 $40 \%$ shrubs on existing unseeded areas. These composition ranges can occur in mosaics within the unseeded areas. Monitoring would occur as described on pages 25 and 28.

c) Provide and maintain habitats within the area capable of supporting the greatest diversity (those minimum species diversity levels presented below) of non-sensitive, native wildlife species at the highest population levels consistent with sustaining that diversity:

* 70 nesting avian species

* 90 migratory and/or seasonal avian species

* 45 resident and/or migratory mammalian species

* 15 resident amphibian and reptile species
Monitoring would occur as described on page 28.

d) Provide and maintain habitats capable of supporting the following population levels of sensitive fish and wildlife species known or strongly suspected of breeding in the area:

* Peregrine Falcon - 5 nesting pairs

* Western Snowy Plover - 100 nesting pairs

* Long-billed Curlew - 20 nesting pairs

* California Bighorn Sheep - 125 individuals

* Loggerhead Shrike - to be set after future inventories

* Pygmy Rabbit - to be set after future inventories

* Ferruginous Hawk - to be set after future inventories

* White-tailed Antelope Groundsquirrel - to be set after future inventories

* White-tailed Jackrabbit - to be set after future inventories

* Oregon Lakes Tui Chub - to be set after future inventories

Monitoring would occur as described on page 28 .

e) Provide and maintain suitable habitats capable of supporting the following sensitive wildlife species known to make seasonal use of the area:

* Bald Eagle - 10 individuals (December - March)

* White-faced Ibis - 50 individuals (February March)

* Black Tern - 150 individuals (migratory; February - June)

Monitoring would occur as described on page 28.

f) Provide, maintain, or restore habitats capable of supporting the following minimum population levels for all sensitive plant species which currently exist or historically existed within the area. Reevaluate management if an existing population declines by $10 \%$ or more over 3 years.

* Desert allocarya (Plagiobothrys salsus) - 50 plants (to be restored)

* Columbia cress (Rorippa columbiae) - to be set after future inventories, if located

* Long-flowered snowberry (Symphoricarpos longiflorus) - to be set after future inventories, if located

Monitored would occur as described on page 28 . 


\section{Goal 9}

Maintain or enhance public education and scientific research opportunities.

\section{Goal 10}

Maintain exploration and development opportunities for leasable, salable, and locatable minerals to provide needed mineral resources, consistent with other listed goals and existing laws, regulations, and policies.

\section{Management Assumptions}

There are a number of assumptions that apply to the Approved Plan Amendment. These are listed below.

1. It must comply with existing laws, regulations, executive orders, and policies.

2. It must be feasible and cost effective.

3. It will be long-term in scope (10-15 year minimum timeframe) and will be modified only when necessary. following BLM planning process.

4. Management will be adaptive and responsive to new data, information, or changing conditions. Continued inventory and monitoring will be required. This is discussed further in the "Plan Review, Monitoring, and Evaluation" and "Inventory and Monitoring" sections. As new information, data, or better techniques or models become available they will be utilized to the extent practicable. Should these suggest or support modification to one or more of the original objectives, this will be accomplished without further public input or a new plan amendment as long as any such new objective(s) is consistent with the goals of this plan amendment.

5. It applies only to BLM-administered lands within the planning area boundary. However, the BLM would emphasize more coordination with other agencies and adjacent landowners and, where possible, enter into partnerships, cooperative agreements, and memorandums of understanding, to be better informed on other activities occurring within the basin and provide input on other proposed actions which may have an adverse impact on the lake ecosystem.

6. It will recognize or be subject to valid, existing rights (i.e. such as mining claims, existing rights-of-way, access to private inholdings, etc.).

7. Any land acquisition proposed will be conducted in accordance with existing requirements to equalize the local land/tax base. The preferred method will be through exchange. Any lands subsequently acquired as a result of implementing the proposed plan which are adjacent to or within an ACEC boundary will automatically be managed in accordance with the goals and objectives specified in this plan amendment and would not require the preparation of a new plan amendment.

8. Implementation of the plan will be coordinated with other agencies, Native American groups, private land owners, and other public members interested in the watershed (through such means as scoping letters, public notices, annual Planning Updates, and consultation/ coordination meetings).

9. Unless specified otherwise, those lands within the planning area outside of any ACEC boundary will continue to be managed in accordance with the existing land use plan, agency policy and direction.

10. Mineral development could occur on private or state lands within or adjacent to the ACEC, as the ACEC designation applies only to lands administered by the BLM. In addition, mineral development is restricted by the Wilderness IMP within Abert Rim WSA (BLM, 1987b).

\section{Plan Amendment Management Direction}

Under the approved plan, a portion (about 49,900 acres) of the original planning area will be designated as an ACEC (Figure 2). For the purposes of impact assessment, a number of assumptions were made concerning what may or may not happen in the future under the proposed plan. It is assumed that certain types of mineral developments and rights-of-way applications could be proposed and approved, but will be subject to protective stipulations. It is also possible that future development(s) may never be proposed. Wildlife and special status species resources may require mitigation in response to such developments. Fire prescriptions will probably be developed and implemented. Current range, recreational, cultural, and other resource management practices will be somewhat protective or restrictive.

\section{Lands Management}

No specific land tenure adjustments were identified in either the High Desert MFP or the draft plan amendment related to the planning area. However, under the proposed alternative, the BLM will continue current policy, which is to block-up 
or acquire, through exchange with a willing party being the preferred method, parcels within the existing interspersed land ownership pattern, in order to improve land management efficiency and when it is in the general public interest.

\section{Rights-of-Way Management}

New rights-of-way could be allowed within the ACEC, but only in accordance with the goals and objectives for VRM class (Goal 6), lake levels, total dissolved solid levels, and water chemistry (Goal 1, objective b), and wilderness interim management policy (none can be located in WSAs). The burden of proof that a new right-of-way proposed within the ACEC met the goals and objectives and, thereby, did not cause an adverse impact on the lake ecosystem, will be on the applicant and will require the preparation of a separate NEPA document.

\section{Roads and Transportation Management}

During the wet season, vehicle traffic may be restricted on those roads lacking subgrade reinforcement where critical erosion is known to occur. No such roads are currently identified. Those roads which are not needed for management, as identified in the transportation plan, could be closed and rehabilitated. Currently, no roads in the planning area listed in the transportation plan have been identified as unnecessary, but due to the potential for future updates to the transportation plan, unneccessary roads could be identified and closed in the future.

Road maintenance will continue as needed (funding permitting). New roads or other transportation features could be constructed in response to discretionary approvals of new rights-of-ways or other permitted developments. However, the burden of proof that such new construction will not cause an adverse impact on the lake ecosystem, will be on the applicant and will require the preparation of a separate NEPA document.

OHV use will be limited to existing roads and trails.

Existing roads and trails refers to those official and unofficial roads and trails which are in existence at the time of ACEC designation, that is, at the time the Approved Plan Amendment/Record of Decision are issued. This will be determined from the Lakeview District transportation plan, USGS topo maps, recent aeriel photographs, staff knowledge of the area, and on-the-ground field checks. Seasonal closures will be placed on the northern playa, in deer/bighorn sheep critical winter range, and near raptor nesting sites, if needed to protect other resource values. Closures will be accomodated by publishing Federal Register and local notices, posting signs, erecting gates or other barriers, and patrols of the area, as needed. Authorized administrative use, on a limited basis, such as law enforcement, emergency search and rescue operations, wildlife surveys, project maintenance, and permittee access may be exempted from these restrictions. For BLM employees and most emergency-related activities, such administrative activities are automatically excepted by the signing of the attached Record of Decsion. Granting of such exceptions to nonBLM employees will occur through the placement of special conditions or stipulations in permits during the permitting process. See also the discussion under Wildlife Management and Recreation Management sections.

\section{Soils Management}

During the wet season, vehicle traffic may be restricted on those roads lacking subgrade reinforcement where critical erosion is known to occur. See also Vegetation Management section.

\section{Air Quality Management}

Prescribed burn plans will be planned and implemented such that burning does not violate state air quality standards.

\section{Hydrology and Water Quality Management}

No discretionary actions under the control of the BLM will be allowed which will violate State of Oregon water quality standards or conflict with Goal 1, objective b. The BLM recognizes water inflow and quality as one of the most important factors affecting lake ecology. However, the authority to control the allocation of water within the basin rests entirely with the Oregon Department of Water Resources and the majority of the headwaters occur on Forest Service lands. The BLM will work cooperatively with both agencies to ensure that future water allocation proposals or projects occurring on Forest Service lands in the basin adequately consider water inflow and quality issues as they relate to potential impacts on the Lake Abert ecosystem. The BLM currenty receives notices from both agencies concerning planned activities going on in the basin. The BLM intends to review all such proposals on a case-by-case basis to determine if they will be detrimental to the lake ecosystem. The BLM intends to comment on such proposals and, if it is determined that a proposal will have an adverse impact on the relevant and important ACEC values, it will officially object or protest the proposed action. However, the final decision on whether to procede with a proposed action rests with the authorized agency (for water rights - the State of Oregon; for land management of Forest Service administered lands - Forest Service). 


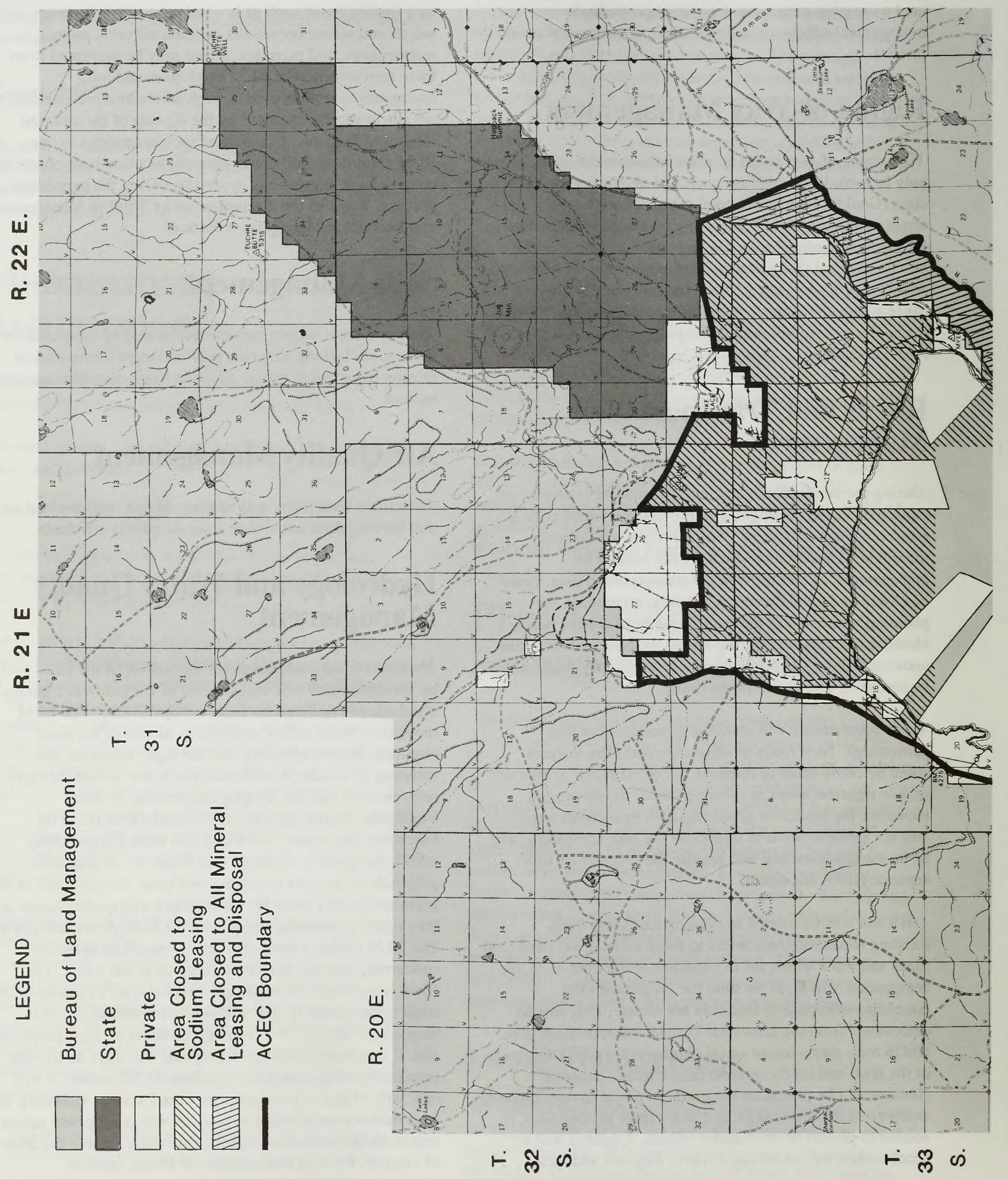




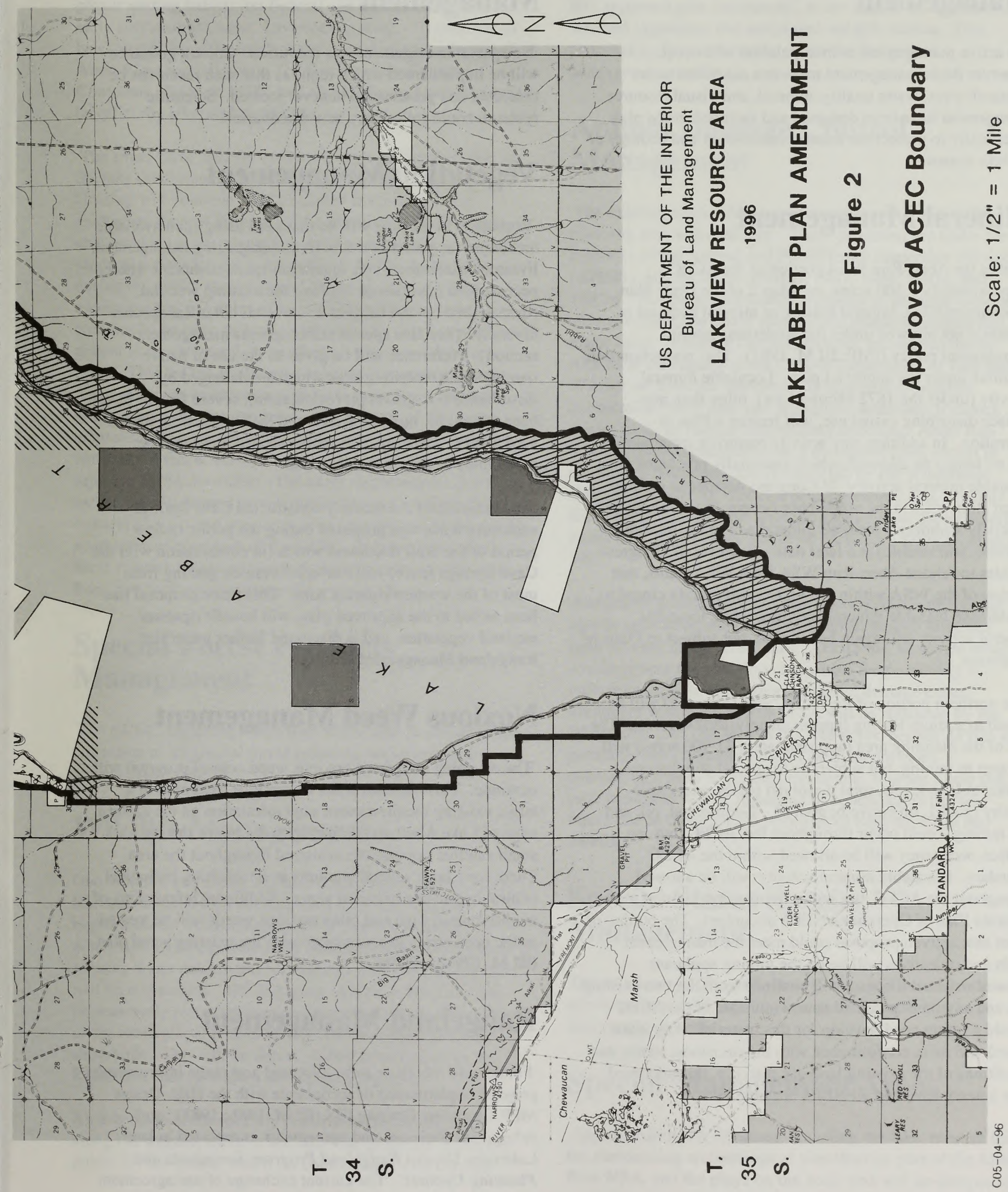




\section{Aquatic Community Management}

No active management or manipulation will occur. However those management measures described under rights-of-ways, water quality, mineral, and visual resource management have been designed and included in the plan specifically to protect the aquatic community and ecology of the lake system.

\section{Mineral Management}

\begin{abstract}
Within the Abert Rim WSA portion of the ACEC (approximately 7,500 acres; see Map 2 of the Draft Plan Amendment/EIS), mineral leasing or mineral disposal is currently not allowed under the wilderness interim management policy (IMP; BLM, 1987). This restriction will continue under the approved plan. Locatable mineral activity (under the 1872 Mining Law), other than nonsurface disturbing casual use, will require a Plan of Operation. In addition, any activity requiring reclamation can no longer be allowed; which essentially precludes most locatable mineral activity. If Congress decides to include Abert Rim WSA in the wilderness system, the area will be officially withdrawn from all mineral activities (locatable, leasable, and salable) at a later date. However, if Congress decides to release Abert Rim WSA from WSA status, that portion of the WSA within the ACEC will remain closed to salable and leasable mineral activities while locatable mineral activity will again be allowed, but subject to Plans of Operation.
\end{abstract}

The northern portion of the ACEC area (Figure 2) will be closed to sodium leasing (approximately 18,000 acres). The rest of the planning area (approximately 31,900 acres) will be open to mining, but subject to to special stipulations related to lake levels, total dissolved solids, and visual quality (goal 1, objective b; goal 6). Geothermal, oil, and gas leasing could occur throughout the ACEC, but no surface occupancy will be allowed within the ACEC boundary. Locatable mineral activity will be allowed throughout the ACEC, but will require preparation of a separate Plan of Operations/NEPA document. The burden of proof that a given proposal could meet the management goals and objectives will be on the mining applicant.

Mineral material disposal will continue from the two existing pits and any other potential sources outside of the ACEC should a future need develop for this material. Any lease issued will be in conformance with the decisions, terms, and conditions of the existing land use plan (i.e. this approved plan amendment) and all NEPA requirements.

\section{Paleontological Resource Management}

No special management was identified. Current guidance will be implemented which requires that such resources be protected and preserved whenever located. Scientific research could follow any new discoveries.

\section{Vegetation Management}

Vegetation in the area will be managed using such available techniques as prescribed fire, livestock grazing management, livestock exclosures, and vegetation reestablishment where necessary to maintain or improve the existing wetland, riparian, and upland habitats and overall botanical species diversity. (See also special status species management section). Preference will be given to the use of native species when reseeding sites which are damaged by disturbance (i.e. gravel pit reclamation), severe fire, or have been treated for noxious weeds and lack an existing native seed source. Existing, non-native seeded areas will be maintained as they currently exist.

An extension of the recently constructed Cave Springs exclosure fence was proposed during the public review period of the draft document which (in combination with the Cave Springs fence) will exclude livestock grazing from most of the western riparian zone. This fence proposal has been added to the approved plan, will benefit riparian/ wetland vegetation, and is discussed further under the Rangeland Management section.

\section{Noxious Weed Management}

The on-going integrated noxious weed control program will continue. This includes plans to continue treatment of a large, existing mediterranean sage infestation on the eastern edge of Lake Abert, extending up to the top of the rim and small satellite populations scattered throughout the area. There have been several attempts at establishing biological control organisms in recent years. Additional infestations of mediterranean sage and other noxious weeds will be treated as the need arises in accordance with the existing weed plan (BLM, 1994b; 1995b).

\section{Rangeland Management}

Forage will continue to be allocated and range improvement projects implemented in accordance with the High Desert MFP, Lakeview Grazing EIS (BLM, 198b; 1983), and subsequent decisions and agreements as reported in later Lakeview District Rangeland Program Summaries and Planning Updates. The current exchange of use agreement 
with the permittee on the north end of the lake (allotment 0425) will continue for the benefit of maintaining snowy plover nesting habitat (on Federal and private land) in an early successional stage. Livestock grazing will continue to be excluded from the southeastern shoreline up to the top of Abert Rim (approximately 7,500 acres of the Paisley Commons allotment 0400) and all AUM's on Abert Rim will be officially allocated to wildlife.

The small Cave Springs exclosure fence on the west side of the lake (allotment 0427) will be maintained in the future. Grazing will continue to be excluded from other small exclosures located throughout the planning area. This will also include maintaining a new exclosure fence (approximately 3.5 miles long; BLM, 1995). In addition, during the public review period, it was pointed out that approximately 6-7 miles of the western shoreline would continue to be open to grazing (though this area has not been grazed in recent years), even after construction of the new fence. This led the ID Team to propose continuing the new fence along the southwestern shore to completely exclude grazing from the riparian zone. The impacts of this fence extension are expected to be similar to those of the recently constructed fence, but will require later evaluation in a separate NEPA document. The exact alignment for this fence extension will depend on the results of future botanical and cultural surveys and may or may not correspond to the actual southwestern boundary of the ACEC. It is expected that these riparian fences wll exclude approximately 1,500 acres from livestock grazing along the western shore.

\section{Special Forest Products Management}

The ACEC, including Abert Rim WSA, will be closed to the collection of all special forest products, consistent with current district policy.

\section{Wildlife Management}

One hundred and eighty bighorn sheep months use on Abert Rim (allotment 0400) will continue to be allocated to bighorn sheep. All remaining AUM's on the west face of Abert Rim will be permanently allocated to wildlife. The 3 existing water catchments for bighorn sheep on Abert Rim will be maintained. Off-Highway Vehicle (OHV) use may be seasonally restricted in raptor nesting areas on Abert Rim or the north playa, if needed to protect nesting raptors or shorebirds. This will be accomplished as described in the Roads and Transportation Management section.

An extension of the recently constructed exclosure fence along the western shore of the lake was proposed during the public review period which (in combination with the new fence) would exclude livestock grazing from most of the western riparian zone. This proposal has been adopted in this approved plan amendment, to the benefit of riparian/ wetland vegetation and associated wildlife habitat. This proposal is discussed further under the Rangeland Management section.

\section{Animal Damage Control Management}

The existing animal damage control programs within the planning area will continue. These programs are under the authority of the Animal and Plant Health Inspection Service (APHIS), not the BLM (APHIS, 1987; 1994; 1995a, and 1995b). The program consists primarily of predator (coyote) control efforts, but could also include problem cougars and black bears. Predator control activities are carried out by APHIS at the request of the Oregon Department of Fish and Wildlife or livestock permittees in response to wildlife depredation (mule deer and pronghorn antelope), livestock depredation, or human health/safety concerns. Abert Rim WSA is currently identified as a no-control area, except in emergency situations, and is restricted by the Wilderness IMP (BLM, 1987b). The rest of the planning area is within the general control zone, with the exception of public safety zones (one-quarter mile buffer on each side) along Highway 395.

Rangeland grasshopper and Mormon cricket control could also be conducted should the need arise, though there has been no need in the recent past. APHIS has identified areas within or near the planning area where the possibility of outbreaks capable of causing economic damage exists. Treatment within Abert Rim WSA will be restricted by the Wilderness IMP (BLM, 1987b). However, neither APHIS or permitees have contacted the BLM in recent years concerning a need to conduct treatment. It is not likely that such treatment will be requested or conducted in the near future due to other budget priorities of both the BLM and APHIS.

\section{Special Status Species Management}

Desert allocarya (Plagiobothrys salsus) will be reintroduced within an improved, existing exclosure where it was historically present.

\section{Special Management Areas}

Approximately 49,900 acres, including the lake, most of the the surrounding archaeological sites/district, part of the Abert Rim WSA, and the playa on the north end will be designated 
and managed as an ACEC with the boundary being established as the top of Abert Rim on the east, an existing powerline on the northeast, an existing county road and private property lines on the north, and an existing jeep trail on the northwest, a new 3.5-mile exclosure fence on the west, and legal/property lines on the southwest as shown in Figure 2. This boundary was derived based on its ability to include all of the lake proper, important scenic and wildlife values, and most of the cultural values.

The current boundary and management of Abert Rim WSA will continue to be guided by the Wilderness Study Report (BLM, 1989a), Final EIS (BLM, 1991a), and Wilderness IMP (BLM, 1987b), pending final Congressional action on wilderness designation.

\section{Fire Management}

All wildfires will be suppressed using a limited suppression strategy in situations where life and property are threatened. Wildfire areas will be reseeded (with an emphasis on the use of native seed) if natural revegetation does not occur or severe soil erosion is an immediate threat. A prescribed burn plan(s) will be developed where appropriate or as needed to meet ACEC management objectives. Prescribed fires will be designed and implemented to encourage natural revegetation by fire-tolerant native species, break up large tracts of monotonous vegetation types into a mosaic of different vegetation types, and reduce the threat of future catastrophic wildfires.

\section{Cultural Resource Management}

A Class III archeological survey of the entire area will be conducted, as time and funding permit. Signs will be placed, in locations where they can be seen by the general public, requesting reporting of any digging or suspicious activity observed in the area. Regular patrols of sites within the area will be performed to protect against unauthorized excavation and monitor general site conditions. Patrols will be conducted by both law enforcement and cultural resource personnel

Cultural site interpretation of some sites will be provided within the area where the public is already stopping and other resources are being interpreted (i.e. the existing Watchable Wildlife site). The existing archaeological district will be expanded to include other eligible sites within approximately one-half mile of the western shore, as time and funding allow.

\section{Traditional Uses}

Native American traditional uses and concerns will be identified through continued consultation with tribal governments and individual Native Americans.

\section{Recreation Management}

With the exception of administrative use, OHV use will be restricted throughout the ACEC to existing roads and trails. Seasonal closures will be placed on the playa at the north end of the lake, in deer/bighorn sheep critical winter range, and near raptor nest sites, if needed. Such closures will be accomplished as described in the Roads and Transportation Management section. In the remainder of Abert Rim WSA east of the ACEC boundary, the OHV designation will remain restricted to existing roads and trails. This restriction will remain in place for that portion of Abert Rim WSA falling within the ACEC should Congress decide to drop Abert Rim WSA from wilderness status. The remainder of the planning area will be open to OHV use.

The existing Watchable Wildlife site on the south end of the lake will be maintained and a new site constructed on the north end of the lake. Hunting and other low-impact recreation opportunities will continue. An existing twotrack road at the mouth of Juniper Creek, east of Highway 395 , will be converted to a foot trail, in a manner consistent with the Wilderness IMP (BLM, 1987b).

\section{Visual Resource Management}

The exiting visual resource classifications (Class I, III, and IV) will be modified to more accurately depict the current visual quality of the area (Figure 3). The Abert Rim corridor will remain in its existing class I category (approximately 22,925 acres). The remainder of the lake and ACEC and part of the rest of the planning area will become Class II (approximately 57,690 acres). The remainder of the planning area will become Class III (approximately 42,380 acres).

\section{Hazardous Materials Management}

Any hazardous substances discovered on BLM-administered lands within the planning area will be investigated and removed in accordance with CERCLA, RCRA, Emergency Planning and Community Right-To-Know Act, and other applicable laws and regulations. Emergency response will include site cleanup, proper notifications, criminal investigations, risk assessment, and other actions consistent with these requirements. Methods will be employed to 
protect the public and BLM employees from exposure to such materials until properly removed and disposed of. All hazardous materials used in management activities within the planning area will be stored, treated, and disposed of in accordance with all applicable legal requirements.

\section{Plan Review, Monitoring, and Evaluation}

The Bureau's planning regulations require that existing land use plan(s) (including plan amendments) be periodically monitored and evaluated at intervals, specified by the appropriate manager (in this case, the District Manager), to determine whether mitigation measures are satisfactory, whether there has been significant changes in other agencies or tribal land use plans/policies, whether there is new data of relevance to the plan, or other reason to warrant amendment or revision of the plan (43 CFR Part 1610.4-9). In the case of the High Desert Management Framework Plan, plan review/monitoring has occurred on about three to five year intervals (1986 and 1991) since the plan was approved in 1983. Except for the statewide evaluation of wilderness areas, this approved plan amendment represents the first amendment to the High Desert Management Framework Plan.

This approved plan amendment will be reviewed and monitored concurrently with the schedule for the High Desert Management Framework Plan. The next review is tentatively scheduled for late calendar year 1996 and is expected on about five year intervals until the plan is replaced by an approved Resource Management Plan or Management Framework Plan revision. Results of the plan review/monitoring process will likely be presented in the annual district Planning Update.

Additional inventory and monitoring will be needed to determine if certain goals and objectives of the approved plan amendment are being met (pages 16-18). However, not all goals and objectives will require extensive inventory and monitoring. The ability to conduct inventory and monitoring is influenced by declining funding levels, other budget priorities, and available personnel; factors which vary from year to year and are often beyond the control of the Lakeview District Office. As discussed in the following section, there are different types of monitoring. The type of monitoring that will be done will vary by goal, intensity, frequency, and interval.

\section{Inventory and Monitoring}

Monitoring will allow management within the area to be adaptive in nature and more responsive to new data, information, or changing conditions. Monitoring can take on three basic forms: implementation (has the proposal been fully implemented?), effectiveness (is the proposal/ management plan having the desired effect or an unexpected undesirable effect? are the goals and objectives being met?), and validation (if the proposal is not having the desired effects, are the management assumptions, goals, or objectives still valid?). Initially, monitoring will focus on implementation and effectiveness. Validation will only be required if the goals and objectives are not being met. The results of such monitoring will be reported in summary form in the Lakeview District's annual Planning Update.

Implementation monitoring will focus on documenting plan implementation as described in the previous section. Those goals where implementation monitoring will occur include 5 , 6,7 , and 10. In most cases, implementation of specific management actions outlined in the plan amendment will cause these goals (and objectives) to be met. The results of such monitoring/plan implementation will be reported in the Lakeview District's annual Planning Update

Effectiveness monitoring will occur for goals 1 and 8 and will become more intense in direct response to landdisturbing development proposals such as sodium leasing. In such an instance, the project proponent will be required to fund or conduct monitoring before, during, and after project development, using scientifically based monitoring protocols. The proponent will be required to report the results of such monitoring to the BLM for evaluation and will also be summarized in the Lakeview District's annual Planning Update.

The types of inventory and effectiveness monitoring which may be conducted (by resource) within the planning area include:

\section{Vegetation/Range Conditions}

\section{1) Additional baseline inventory of riparian/wetland} vegetation may occur, provided funding is available. Some such inventory work has been accomplished, but may need to be supplemented in the future. This will most likely be accomplished through contract with a credible academic institution under the challenge cost-share or similar funding mechanism (BLM shares the cost with other sources/ participants). The work that has been done to date involved monitoring riparian/wetland vegetation at permanent frequency transects in 5 or 6 key locations around the lake. Photoplots could also be used for quantifying vegetation change. If more than $10 \%$ change in species diversity occurs ( $75 \%$ confidence level) over 3-year period, this will be viewed as not meeting the plan's stated goals and objectives (Goal 1, objective b and Goal 8, objective f) and management will be reevaluated. 


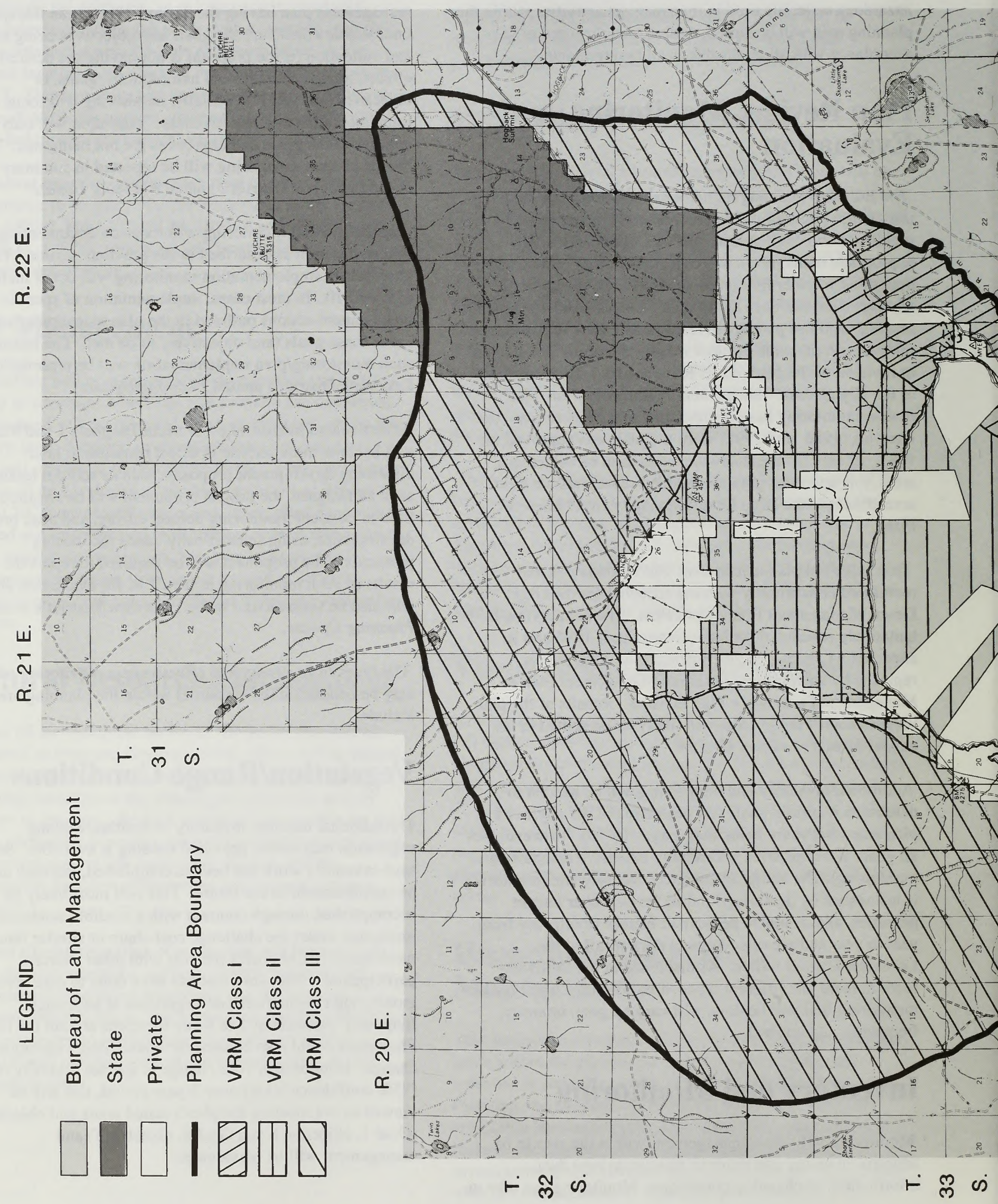




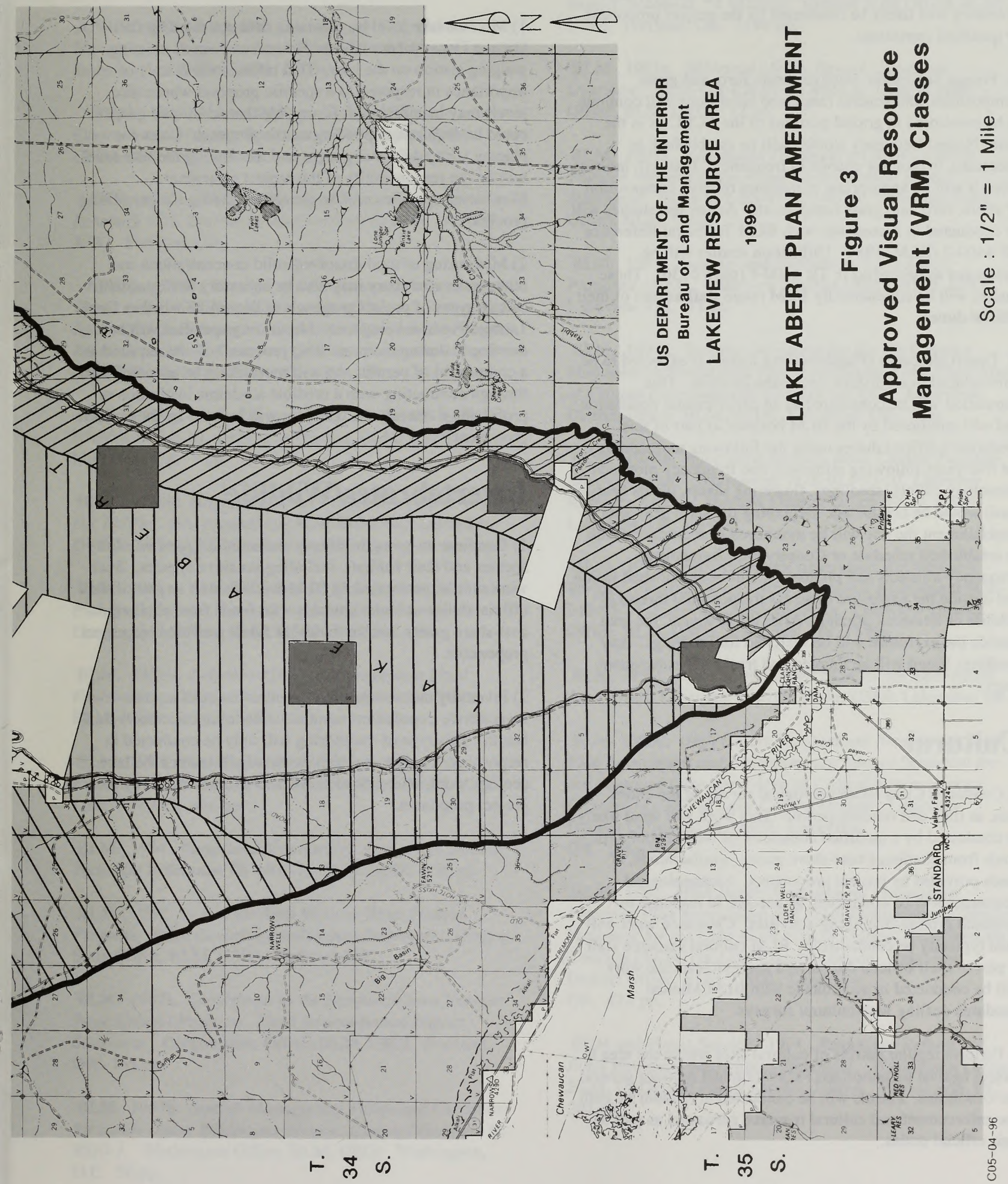


Additional botanical inventory may occur in the area. In the case of a permitted land or water disturbing activity, such inventory will likely be conducted by the project proponent or qualified consultant.

2) Forage utilization, relative shrub, forb, and grass composition, and general rangeland conditions will continue to be monitored in grazed portions of the ACEC as in the past. Nested frequency studies will be established, as necessary, to monitor change in frequency. This will indicate when it will be appropriate to measure relative composition of shrub, forb, and grass components. Actual use studies will be conducted in accordance with BLM Technical Reference TR 4400-2 (BLM, 1984). Utilization studies will be conducted as described in TR 4400-4 (page 6,36). These studies will be conducted by BLM range staff as part of their official duties.

3) Desert allocarya (Plagiobothrys salsus) is expected to be reintroduced in an historic enclosure location. This population will be considered as an experimental population and will monitored by the BLM botanist as part of this specialist's official duties using the following methodology: for five years following reintroduction frequency plots and phenology counts (seedlings, flowering plants, plants bearing seed) would be conducted. Beginning the sixth year after establishment the site will be monitored in accordance with an established schedule or Conservation Agreement.

Frequency transects and photoplots will be established inside and outside the exclosure to assess the potential threats of wildlife or livestock grazing. After the first year, the area outside the exclosure will be searched for seedlings. Any seedlings found will be flagged and tracked in subsequent years.

\section{Cultural}

1) Conduct a Class III archeological survey of the entire area, as time and funding permit. This work will most likely be conducted by a qualified contractor or field school with funds from challenge cost-share grants, similar funds, or funds provided by project proponents. Archaeological clearances will be conducted, as needed, in response to proposed ground-disturbing activities. Clearance work will most typically be conducted by BLM cultural resource staff as part of their official duties. All survey/clearance work will be conducted in accordance with BLM Manual standards dealing with cultural surveys.

2) Perform regular patrols of cultural sites within the area to protect against unauthorized excavation and monitor general site conditions. Patrols will be conducted at random by both law enforcement and cultural resource personnel as part of their official duties.

\section{Water Level/Quality}

1) Monitor lake level by obtaining data collected by the Oregon Department of Water Resources from an existing gauging station on the lake. This information is only of importance in response to a specific proposal where lake levels may be affected. It is possible that additional gauges could be required, depending on the proposal. Costs for placing such additional gauges and monitoring the lake level will be the responsibility of the project proponent.

Monitoring specifics will be developed during the permitting process.

2) Monitoring of total dissolved solid concentrations and other water chemistry may also be necessary in response to certain types of project proposals to determine whether Goal 1 , objective $b$, is being met. Monitoring specifics will be developed during the permitting process, will be required as a component of permit, and will most likely be accomplished through contracting with a credible academic institution or professional consultant. The cost will be born by the project proponent.

\section{Invertebrates/Wildlife}

1) Continue on-going inventory and monitoring of wildlife species and their habitats, including sensitive species. Such work will be performed by BLM wildlife staff as part of their official duties or under contract with funds from challenge cost-share grants, similar funds, or funds provided by project proponents.

2) Inventory and monitor relative abundance of aquatic invertebrate populations as an indicator of aquatic ecological health. This type of monitoring will only be conducted in response to a proposal which potentially threatens the lake ecology using scientific methods and will be funded by the project proponent. 


\section{Literature Cited}

APHIS. 1987. Rangeland Grasshopper Cooperative Management Program. Final Environmental Impact Statement. APHIS, USDA. 552 pp.

APHIS. 1994. Animal Damage Control. Final Environmental Impact Statement. 3 Volumes. APHIS, USDA. Washington, D.C.

APHIS. 1995a. Wildlife Damage Management in the Roseburg ADC District in Southwestern Oregon. APHIS, ADC. Portland, OR.

APHIS. 1995b. Site-Specific Environmental Assessment Tiered to the 1987 Final Environmental Impact Statement for Rangeland Grasshopper Cooperative Management Program. Klamath and Lake Counties, Oregon. Assessment Number OR-04-95. APHIS, USDA. Portland, OR.

BLM. 1978a. Black Canyon Gravel Pit No. OR-I-78-2I. EA\#OR-010-8-10. Lakeview District, BLM, USDI. Lakeview, OR. 9 pp.

BLM. 1978b. Hogback Summit - Pikes Ranch Gravel Pit OR 10732. EA Amendment \#OR-010-8-38. Lakeview District, BLM, USDI. Lakeview, OR. 2 pp.

BLM. 1982a. Wilderness Studies Management Framework Plan Amendments. Summary of Land Use Alternatives. Oregon State Office, BLM, USDI. Portland, OR.

BLM. 1982b. Lakeview Grazing Management Final Environmental Impact Statement. Oregon State Office, BLM, USDI. Portland, OR. 263 pp.

BLM. 1983. High Desert Resource Area Management Framework Plan. Lakeview District Office, BLM, USDI. Lakeview, OR. var. pp.

BLM. 1984. Rangeland Monitoring. Actual Use Studies. Technical Reference TR 4400-2. BLM, USDI. 130 pp.

BLM. 1985. Northwest Area Noxious Weed Control Program. Final Environmental Impact Statement. Oregon State Office, BLM, USDI. Portland, OR.

BLM. 1987a. Supplement to the Northwest Area Noxious Weed Control Program. Final Environmental Impact Statement. Oregon State Office, BLM, USDI. Portland, OR. 151 pp.

BLM. 1987b. Interim Management Policy and Guidelines for Lands Under Wilderness Review. Update Document $H$ 8550-I. Washington Office, BLM, USDI. Washington,

D.C. $56 \mathrm{pp}$.
BLM. 1989a. Oregon Wilderness. Final Environmental Impact Statement. 4 volumes. Oregon State Office, BLM, USDI. Portland, OR. 2190 pp.

BLM. 1991a. Wilderness Study Report. Statewide Overview. BLM-OR-EA-91-45-8561.6. Oregon State Office, BLM, USDI. $12 \mathrm{pp}$.

BLM. 1991b. Vegetation Treatment on BLM Lands in Thirteen Western States. Final Environmental Impact Statement. BLM-WY-ES-91-022-4320. Wyoming State Office, BLM, USDI.

BLM. 1993. Analysis and Evaluation, Lake Abert Proposed ACEC. Lakeview District Office, BLM, USDI. Lakeview, OR. $13 \mathrm{pp}$.

BLM. 1994a. Scoping Document for the High Desert Management Framework Plan Amendment, Lake Abert Area of Critical Environmental Concern (ACEC). Lakeview District Office, BLM, USDI. Lakeview, OR. 7 pp.

BLM. 1994b. Integrated Noxious Weed Control Program. Environmental Assessment \#OR-013-03-01, Lakeview Resource Area. Lakeview District Office, BLM, USDI. Lakeview, OR. 43 pp.

BLM. 1995a. Environmental Assessment for the Cave Springs Riparian Fence. Environmental Assessment \#OR010-95-04, Lakeview Resource Area. Lakeview District Office, BLM, USDI. Lakeview, OR. 13 pp.

BLM. 1995b. Weed Management Plan for the Lake Abert Area. Draft. Lakeview District, BLM, USDI, Lakeview, OR

BLM. 1995c. High Desert Management Framework Draft Plan Amendment and Environmental Impact Statement for the Proposed Lake Abert Area of Critical Environmental Concern (ACEC) in Lake County, Oregon. Lakeview District Office, BLM, USDI. Lakeview,

OR. $106+$ pp.

BLM. 1996. High Desert Management Framework Proposed Plan Amendment and Final Environmental Impact Statement for the Lake Abert Area of Critical Environmental Concern (ACEC) in Lake County, Oregon. Lakeview District Office, BLM, USDI. Lakeview, OR. $42+$ pp.

BLM and Forest Service. 1994. Rangeland Reform ' 94. Final Environmental Impact Statement. Washington Office, BLM, USDI, and Forest Service, USDA. Washington, DC. $201 \mathrm{pp}$. 
Department of Land Conservation and Development. 1994. Oregon's Statewide Planning Goals. 1994 Edition. Salem, OR. 36 pp.

CEQ. 1981. Forty Most Asked Questions Concerning CEQ's National Environmental Policy Act Regulations (40 CFR 1500-1598). Federal Register 46 (55): 18026-18038.

Lake County. 1979. Land Use Atlas. A Comprehensive Plan Supplement. Prep. by Lynn D. Steiger \& Associates, Inc. for Lake Co. Planning Dept., Lakeview, OR. 141 pp.

Lake County. 1983. Amendments to the Lake County Atlas, a Supplement to the Lake County Comprehensive Plan. Lake Co. Planning \& Building Office, Lakeview, OR. 21 pp.

Lake County. 1989a. Comprehensive Land Use Plan, Lake County, Oregon. Housing, Economic, and Population Elements, Goal Exceptions and Buildable Land Inventories. Orig. prep. by Lynn D. Steiger \& Associates, Inc., Revision prep. by A. R. Brown Planning Consultant for Lake Co. Planning Dept., Lakeview, OR. 197 pp.
Lake County. 1989b. Lake County Zoning Ordinance. Lake Co., Lakeview, OR. 146 pp.

Lake County. 1989c. Lake County Land Development Ordinance of 1980. Lake Co., Lakeview, OR. 41 pp.

Lake County. 1992. Lake County Emergency Ordinance and Interim Public Land Management Plan. Lake Co., Lakeview, OR. $17 \mathrm{pp}$.

Natural Heritage Advisory Council to the State Land Board. 1993. Oregon Natural Heritage Plan. Salem, OR. 158 pp.

ORE-CAL Resource Conservation and Development Council. 1995. Area Plan. 27 pp. 



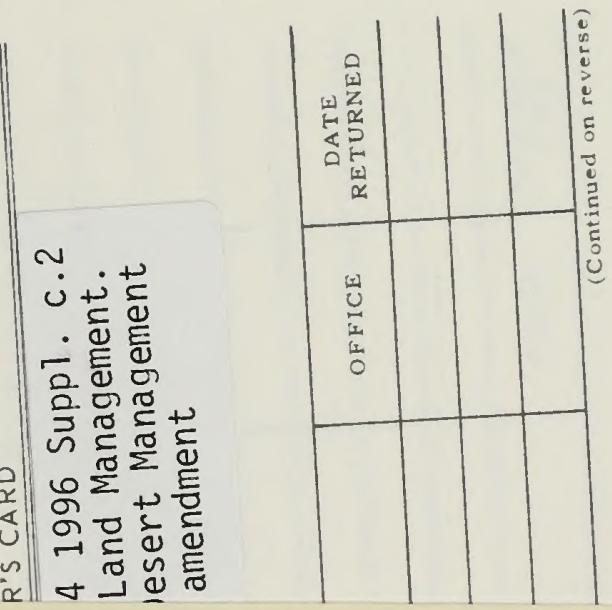

TD 171.3 .07 H54 1996 Suppl. c.2 U.S. Bureau of Land Management. Lakeview High Desert Management framework plan amendment

$+$

$+4$

BLM LIBRARY

RS 150 A BLDG. 50

DENVER FEDERAL CENTER

P.O. BOX 25047

DENVER, CO 80225 

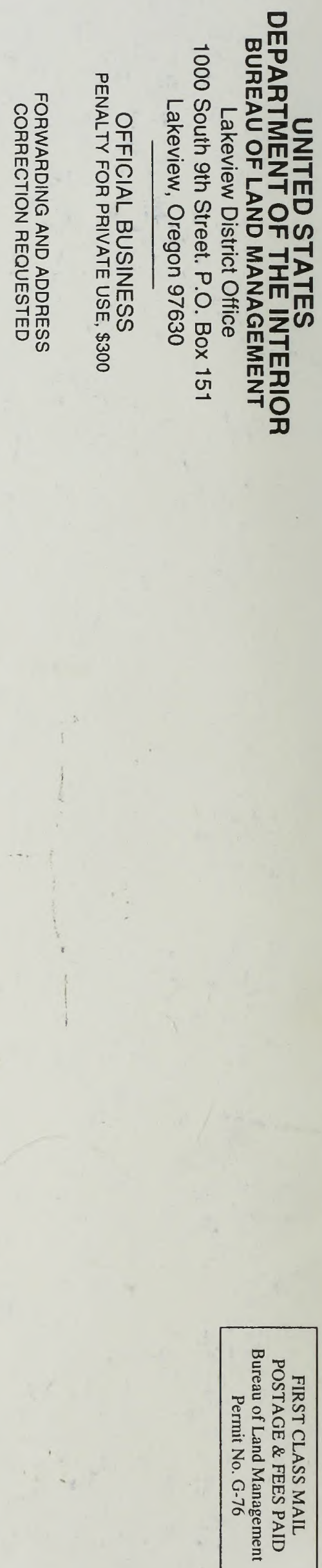